\title{
Foreign Capital Flows And Economic Globalization On Financial Development Dynamics: A Comparative Evidence On Top And Bottom Remittance And FDI- Receiving Regions With New Policy Insights
}

Shreya Pal ( $\sim$ share2shreya@gmail.com )

Indian Institute of Technology Kharagpur

\section{Research}

Keywords: Remittance, Financial development, Economic globalization, Panel model, Developing regions

Posted Date: February 15th, 2022

DOl: https://doi.org/10.21203/rs.3.rs-1108265/v1

License: (c) (1) This work is licensed under a Creative Commons Attribution 4.0 International License. Read Full License 


\section{Abstract}

In the perspective of Mishkin, (2009) hypothesis, this study is encouraged to investigate the consequences of remittance and $\mathrm{FDI}$, which is a part of economic globalization, on financial development dynamics (financial institutions and markets) in the top (Europe and Central Asia) and bottom (Sub Saharan Africa) remittance and FDI receiving developing regions by using the balanced panel data from 1984-2020. We used Institutional quality, economic growth, inflation, and government investment as control variables in the financial development dynamics function. The findings from FMOLS and DOLS indicate that institutional quality is a pillar for growing economic globalization and financial development globally. This concept satisfies the Mishkin, (2009) Hypothesis. The long-run partial elasticity of financial development positively enhances the remittance, FDI, and economic globalization for both panel regions. From a policy perspective, we propose that all developing countries should utilize domestic financial sources for consumption purpose. For that, a strong regulatory and supervisory framework requires to implement to each country which helps to minimizes financial stability risks. Ultimately FDI and remittance with favourable regulations, especially financial market regulations, will assist to fully utilize the benefits of the spill over effects of foreign flows at their maximum level.

\section{JEL codes: F24; F60; G10; G20; C33; 018}

\section{Introduction}

The past outbreak of global financial crises summarizes the importance of foreign capital inflow. As these global crisis makes the financial sector unstructured and disfigured. The evidence of negative impact of the malfunctioned financial system observed globally. At that point of time, foreign flows act as an incarnation for the affected economy by injecting the money flows. This outcome catching the eyes of the researchers and policymakers because financial flows can modify the financial sector, which leads to higher economic growth in long-run.

However, foreign capital inflows constantly play a necessary role for developing countries. According to Siddiqui, (2014), foreign capital inflows provide the capital needed for investment and growth, which ultimately enhance the performance of the overall economy of any country. It also widening and strengthening the financial markets, accelerate the transfer of technology and management expertise, and enhance liquidity, which expands the new job opportunities and boosts overall economic growth (Ajayi, 2006).

Some researchers also find adverse effects of foreign capital inflows like Baharumshah \& Thanoon, (2006); Berument \& Dinçer, (2004). They concluded that foreign capital inflows increase inflationary pressures, prompt monetary diversification, current account deficits, and exposure to external shocks and restrict the advantages of domestic policy instruments, etc. Ultimately these factors can badly impact the overall financial system. As we know, malfunctioning financial systems can directly or indirectly affect the economy by misusing resources, reducing savings, and enhancing speculation. As a repercussion, reduction of investment, a misallocation of scarce resources take place. These adverse effects of the financial system lead to the economy's deterioration by rising unemployment and poverty. The 2008 global financial crisis has also clarified the impact of malfunctioning financial systems on the affected economy. Since the breakout of the global crisis, an adverse impact on the rest of the world has been noticed. Highlighting the advantages of appropriate policy measures and introduces the different factors for financial development leads to minimization of the negative impact of the unstructured 
financial system. Therefore, we need to concentrate on financial development factors, which combined can maximize the utility of financial development.

As we observe from the couple of empirical studies that economic growth and financial development are interrelated with each other (Akisik, 2013; Ang, 2008; Beck et al., 2003; Demetriades \& Law, 2006; Djalilov \& Piesse, 2011; Fung, 2009; Hsueh et al., 2013; Law, 2008; Levine, 2003; Liu \& Hsu, 2006; Zhang \& Wu, 2012). Alternatively, several empirical studies (Burnside \& Dollar, 2000; Chenery \& Strout, 1966; Pradhan et al., 2008) find evidence that foreign flows have a positive growth impact, while some (Chami et al., 2005; Griffin \& McKinley, 1994; Mah, 2010) suggests adverse effect or no effect at all on economic growth. Therefore, these literatures summarized that economic growth could directly impact financial development, but foreign financial flows can indirectly affect it by influencing economic growth. Also, the globalization-financial development nexus highlights the attention of researchers and policymakers. In such a scenario, Mishkin, (2009) appeared with a new strand in empirical research on applied finance and macroeconomics. According to him, a new ingredient of empirical research has come out. He added that globalization could bring financial development by stimulating institutional qualities in developing countries. Institutions with strong property rights, effective legal systems, and sound financial regulations, can rapidly upgrade the financial development in developing economies.

As per World Bank, 2014, remittance became the fastest mode of money transferring throughout the world. The remittances flow in low and middle-income countries become \$343 billion in 2010; it again enhances to \$449 billion in 2015 and in 2016 it become \$442 billion. It again rose by \$528 billion in 2018 and in 2019 it became $\$ 551$ billion. But remittance flows to low and middle-income countries in 2020 , declines by $20 \%$, i.e., $\$ 540$ billion, because of the economic crisis happens during the Covid-19 Pandemic situation. At that time, most of the migrants lost their job which raises the unemployment and poverty (World Bank, 2021). But the decline rate of remittance in 2020 (1.6\%) is lesser than the 2009 global financial crisis (4.8\%). Remittance also reduces the flow of foreign direct investment and overseas development assistance in 2020. As per the study of Peres et al. (2018), FDI received more by the developed countries rather than developing countries before the global financial crisis in 2008 , but time has changed the graph, after the crisis it enhances by $35 \%$ in the developing countries.

However, this study is interested in research on the impact of foreign flows on financial development because of the consequences of financial flows in overall nations. The empirical studies discussed above, all have one thing in common: each study examines the impact of these external factors and ignores the impact of combined foreign flows, i.e., globalization. It is also surprising to note that there is no empirical evidence on the remittance and FDI-financial development nexus in region-based developing economies. In an attempt to fill the research gap in the current literature, this study empirically analyses the impact of remittance and FDI on financial development dynamics. As remittance and FDI is a part of economic globalization, we will also try to check the impact of economic globalization on financial development dynamics for these two regions.

- Please insert Figure 1

Therefore, this study only takes remittance and FDI because they are the top two foreign financial flows. In this perspective, Figure 1 states that an up-sloping trend of remittance and FDI flows leads to a reappearance of it and gaining more importance day by day in the Research field. As we know that international financial flows are coming to developing countries through firms, financial institutions and markets, and government sources. Concerning the current scenario, Remittances is the top financial flows of developing countries followed by FDI, official development Assistance and portfolio equity (Figure 1). So, remittance shows an increasing trend which is 
impressive in nature. However, in modern times most devastating financial crises are the Asian crisis of 1997 and the financial crisis of 2007-08. The Asian crisis of 1997 originated from Thailand and spread over East Asia later. According to the World Development Indicator, during the 1997 crisis growth rate of remittance was higher than the net FDI inflows growth rate. In 1997, remittance was higher than the rest of the year, but FDI was lesser than remittance. In the year 2007-08, another crisis happened in the United States because of severe contraction of liquidity in the global financial market, as an effect, U.S. Housing Market collapsed. According to the dataset collected from World Development Indicator, FDI is regularly decreasing, but remittances increase at a constant rate for 2007-09. Besides this, remittances have increased significantly from 2015-2019, But in between 20192020 , the data are dropping because of the pandemic crisis that happens in this duration. Most of the migrants came home during that period which automatically leads to degradation of the remittance amount. However, in spite of the ups and downs of the financial flows, we are choosing the top two financial flows i.e., remittance and FDI for our analysis.

Moreover, according to the World Bank data from its latest version of "Migration and Development Brief", Regionwise, Europe and Central Asia (ECA) have the highest amount received from remittance and FDI, and Sub-Saharan Africa (SSA) has the lowest remittance and FDI receiving region. The report also added that remittance inflows increase in Latin America and the Caribbean (6.5 percent), South Asia (5.2 percent), and the Middle East and North Africa (2.3 percent). However, it reduces in East Asia and the Pacific (7.9 percent), Europe and Central Asia (9.7 percent), and Sub-Saharan Africa (12.5 percent). Therefore, a dropping rate of remittance in Europe and Central Asia and Sub-Saharan Africa also highlights the importance to check the loopholes of this regions. These are the reasons finds ECA and SSA region as a top and bottom Remittance and FDI receiving region for this study. Whereas figure 2 and figure 3 are showing the proof of choosing these two regions as top and bottom in both the cases of Remittance and FDI receiving region. Therefore, it will be interesting to take these regions as our sample area for our analysis.

- Please insert Figure 2

- Please insert Figure 3 -

However, this comparative analysis between the ECA and SSA region, based on the impacts of remittance and FDI on the pattern of financial development, has not been analysed before. Against this backdrop, we aim to study the impacts of Remittance, FDI, and economic globalization on financial development by considering other critical macroeconomic factors, including institutional quality, Economic growth, domestic investment, and inflation, using annual data over 1984-2020. Therefore, we are trying to see the behaviour of the top Remittance and FDI receiving region and bottom Remittance and FDI region on financial development dynamics, which will help in policy implication in the near future.

Therefore, our study adds value to the existing literature for several reasons. As per my knowledge, this regionbased study is the first study that considers the various dimensions of financial development, like financial institutions and financial markets (access, depth, and efficiency). On this reason, it becomes productive in case of financial development that ensures every aspects of the financial sector at the same time. The financial development dataset is constructed by Svirydzenka, (2016), a recently published financial development index in the International monetary fund. As Remittance and FDI are part of globalization, that is the reason our study not only considers Remittance and FDI as our primary independent variable but also it observes the impact of economic globalization for robustness. This study considers the globalization index by Gygli et al., (2019), a 
newly published KOF globalization index dataset in the International monetary fund for testing this hypothesis. Overall, this study gives a broader sense of identifying the impact of remittance, FDI, and economic globalization on financial development, which can add value to the research field by providing new policy measures for future endeavours.

The structure of the paper is as follows: Section 2 is all about the review of the related literature. Section 3 is related to the Theoretical framework. Section 4 describes the data sources used in this study, and Sections 5 and 6 describe the Methodology followed by Results and discussion of this study. Finally, the conclusion, Policy implications, and possible directions for future research are described in Section 7.

\section{Related Literature Review}

\subsection{Remittance-Financial development nexus}

Remittance coming from migrant workers also provide a good amount of household savings for their family. Generally, remittance is used for consumption, or may be deposits into financial institutions, or may be invested to some projects. The proper allocation of capital provides the efficiency in economy and raises the productivity as well, which finally leads to the higher economic growth. On this perspective, Burgess \& Pande, (2005) finds that remittance enhances the savings and loans for investment in financial institutions, which as a result, gives a substantial impact on financial development. So, the remittance-financial development nexus has become a noticeable topic for researchers as it covers various aspects of socio-economic development. Rapoport \& Docquier, (2006) describes about these different aspects of remittances briefly in their study.

A few studies works on the association between remittances and financial development (Ang, 2008; Hsueh et al., 2013; King \& Levine, 1993; Liu \& Hsu, 2006). Gupta et al., (2009) also report the positive relation between remittance and financial development in Sub-Saharan Africa. Whereas Giuliano \& Ruiz-Arranz, (2009) states that remittance impacts growth and financial development using cross-country analysis. This result is supported by the study by Aggarwal et al., (2011) for 109 developing countries; Chowdhury, (2011) for Bangladesh; Fromentin, $(2017,2018)$ for Latin America and the Caribbean, as well as in developing countries; Bhattacharya et al., (2018) for 57 highest remittance recipient countries; Williams, (2016) for 45 countries; Donou-Adonsou et al., (2020)for top recipient countries of Sub-Saharan Africa. On the other hand, remittances enhance size and efficiency of financial sector in 94 non-OECD countries.

Oppositely, some economists observes an adverse relation between remittance and financial development. Nyamongo et al., (2012) found that the volatility of remittances appears to harm the growth of African economies. Remittances becomes a complement to financial development. Whereas remittances reduces credit markets by dropping the credit demands (Calderon et al., 2008). The negative association between the remittances and financial development has been witnessed by the study of Brown et al., (2013) and Coulibaly, (2015) for Sub-Saharan Africa.

However, the linkage between remittance and financial development for top and bottom remittance-FDI receiving regions, provides a great insight into the way of financial development path.

Please insert Table 1 
Table 1

Literatures related to Remittance-Financial Development nexus

\begin{tabular}{|c|c|c|c|c|}
\hline Study & Sample & Region & Methodology & Findings \\
\hline $\begin{array}{l}\text { Aggarwal et } \\
\text { al., (2011) }\end{array}$ & $\begin{array}{l}1975- \\
2007\end{array}$ & $\begin{array}{l}109 \text { developing } \\
\text { countries }\end{array}$ & $\begin{array}{l}\text { GMM } \\
\text { regression }\end{array}$ & $\begin{array}{l}\text { Across the developing countries, a positive } \\
\text { association exists between remittances } \\
\text { and financial development. }\end{array}$ \\
\hline $\begin{array}{l}\text { Ahamada \& } \\
\text { Coulibaly, } \\
(2011)\end{array}$ & $\begin{array}{l}1980- \\
2008\end{array}$ & $\begin{array}{l}70 \text { developed and } \\
\text { developing } \\
\text { countries }\end{array}$ & $\begin{array}{l}\text { Panel } \\
\text { smooth } \\
\text { transition } \\
\text { regression } \\
\text { (PSTR) } \\
\text { approach }\end{array}$ & $\begin{array}{l}\text { An effective and efficient Financial } \\
\text { development leads to better use of } \\
\text { remittances. }\end{array}$ \\
\hline $\begin{array}{l}\text { Bang et al., } \\
(2015)\end{array}$ & $\begin{array}{l}1986- \\
2005\end{array}$ & 84 countries & $\begin{array}{l}\text { OLS and } \\
\text { 2SLS }\end{array}$ & $\begin{array}{l}\text { Remittance is used as the source of } \\
\text { development finance. }\end{array}$ \\
\hline $\begin{array}{l}\text { Bhattacharya } \\
\text { et al., (2018) }\end{array}$ & $\begin{array}{l}1992- \\
2012\end{array}$ & $\begin{array}{l}57 \text { highest } \\
\text { remittances } \\
\text { receiving } \\
\text { developed and } \\
\text { developing } \\
\text { countries }\end{array}$ & $\begin{array}{l}\text { Pooled OLS } \\
\text { and the } \\
\text { dynamic } \\
\text { system } \\
\text { GMM }\end{array}$ & $\begin{array}{l}\text { A positive and significant effect of } \\
\text { remittance found for financial } \\
\text { development. }\end{array}$ \\
\hline $\begin{array}{l}\text { Cherif \& } \\
\text { Dreger, } \\
(2016)\end{array}$ & $\begin{array}{l}1990- \\
2007\end{array}$ & $\begin{array}{l}\text { The Middle East } \\
\text { and North African } \\
\text { (MENA) region }\end{array}$ & $\begin{array}{l}\text { Fixed effects } \\
\text { model }\end{array}$ & $\begin{array}{l}\text { Faster real economic integration is crucial } \\
\text { to improving financial development and } \\
\text { ultimately gives a higher GDP growth. }\end{array}$ \\
\hline $\begin{array}{l}\text { Combes \& } \\
\text { Ebeke, } \\
(2011)\end{array}$ & $\begin{array}{l}1975- \\
2004\end{array}$ & $\begin{array}{l}87 \text { developed and } \\
\text { developing } \\
\text { countries }\end{array}$ & $\begin{array}{l}\text { System } \\
\text { GMM and } \\
\text { Ordinary } \\
\text { Least } \\
\text { Squares } \\
\text { (OLS) }\end{array}$ & $\begin{array}{l}\text { Insurance played by remittances a more } \\
\text { critical role in less financially developed } \\
\text { countries. }\end{array}$ \\
\hline $\begin{array}{l}\text { Cooray et al., } \\
(2016)\end{array}$ & $\begin{array}{l}1970- \\
2012\end{array}$ & $\begin{array}{l}103 \text { developing } \\
\text { countries }\end{array}$ & $\begin{array}{l}\text { Two-stage } \\
\text { least } \\
\text { squares } \\
\text { (2SLS) and } \\
\text { System } \\
\text { GMM. }\end{array}$ & $\begin{array}{l}\text { Remittances help to promote long-run } \\
\text { economic growth and development. }\end{array}$ \\
\hline $\begin{array}{l}\text { Fromentin, } \\
(2018)\end{array}$ & $\begin{array}{l}1970- \\
2013\end{array}$ & $\begin{array}{l}32 \text { countries of } \\
\text { Latin } \\
\text { America and the } \\
\text { Caribbean }\end{array}$ & $\begin{array}{l}\text { OLS, fixed } \\
\text { effects, and } \\
\text { dynamic } \\
\text { GMM } \\
\text { estimates }\end{array}$ & $\begin{array}{l}\text { Higher remittances helps to expand and } \\
\text { deepen the financial sector and vice versa. }\end{array}$ \\
\hline $\begin{array}{l}\text { Giuliano \& } \\
\text { Ruiz-Arranz, } \\
(2009)\end{array}$ & $\begin{array}{l}1975- \\
2002\end{array}$ & $\begin{array}{l}100 \text { developing } \\
\text { countries }\end{array}$ & $\begin{array}{l}\text { OLS and } \\
\text { System } \\
\text { GMM }\end{array}$ & $\begin{array}{l}\text { In less developed countries, remittances } \\
\text { enhances the economic growth by } \\
\text { providing a path of financial investment } \\
\text { and reduce the liquidity constraints. }\end{array}$ \\
\hline $\begin{array}{l}\text { Mundaca, } \\
(2009)\end{array}$ & $\begin{array}{l}1970- \\
2002\end{array}$ & $\begin{array}{l}\text { Latin America and } \\
\text { the Caribbean }\end{array}$ & GMM & $\begin{array}{l}\text { Easy and quick financial services lead to } \\
\text { more inflow of remittances and enhance } \\
\text { the economic growth. }\end{array}$ \\
\hline
\end{tabular}




\begin{tabular}{|lllll|}
\hline Study & Sample & Region & Methodology & Findings \\
\hline $\begin{array}{l}\text { Nyamongo et } \\
\text { al., (2012) }\end{array}$ & $\begin{array}{l}1980- \\
2009\end{array}$ & $\begin{array}{l}36 \text { countries in } \\
\text { Africa }\end{array}$ & $\begin{array}{l}\text { Fixed effects } \\
\text { and the } \\
\text { random- } \\
\text { effects } \\
\text { models, OLS }\end{array}$ & $\begin{array}{l}\text { Remittances harm growth, but it enhances } \\
\text { financial development. }\end{array}$ \\
$\begin{array}{l}\text { Sobiech, } \\
(2015)\end{array}$ & $\begin{array}{l}1960- \\
2010\end{array}$ & $\begin{array}{l}\text { 5 countries as } \\
\text { small, 2 as oil- } \\
\text { producing, and 54 } \\
\text { developing } \\
\text { countries. }\end{array}$ & $\begin{array}{l}\text { GMM and } \\
\text { fixed effect } \\
\text { model }\end{array}$ & $\begin{array}{l}\text { Remittances have adverse growth effects } \\
\text { in developing countries, while in least } \\
\text { advanced countries, it gives positive } \\
\text { impact. }\end{array}$ \\
\hline
\end{tabular}

\subsection{FDI-Financial development nexus}

According to the World Bank's data, FDI is also another great foreign flows over the last few decades. It attracts the considerable attention from the policymakers and researchers (Durusu-Ciftci et al., 2017). FDI can enhance financial development by working as financial intermediation. This financial development helps any economy by mobilizing savings, risk management, efficient allocation of capital, etc., which can enhance the economic growth of any nation (Alfaro et al., 2004; Durham, 2004; Hermes \& Lensink, 2003). FDI also helps to bring the advancement in technology and management, which brings economic growth and development (Alfaro et al., 2010). A positive relation finds between FDI and financial development by the study of Soumaré \& Tchana Tchana, (2015). Studies like, Saidi et al., (2018)stand for the same result for low income countries. Some other empirical studies also get positive impacts of FDI on financial development (Balasubramanyam et al., 1996; Borensztein et al., 1998; De Mello Jr, 1997; De Mello, 1999; Hansen \& Rand, 2006).

Conversely, several studies report the negative impact of FDI (Aitken et al., 1997; Grilli \& Milesi-Ferretti, 1995). Harrison \& Aitken, (1999) find that the net effect of FDI on productivity is relatively less. Similarly, Haddad \& Harrison, (1993) didn't find any positive impact of FDI on economic growth in their study, where they examined the relationship between economic growth and FDI. Whereas Kosack \& Tobin, (2006) found out that FDI is not more effective than aid in funding development theoretically and empirically. Also, they added that FDI and aid affect development differently. Hanif \& Shariff, (2016) didn't find any association between FDI and Financial development in ASEAN countries. This result again supported by Bayar \& Gavriletea, (2018) for Central and Eastern European Union countries, Henri et al., (2019) for middle income countries.

However, most of the studies finds that FDI works as a channel of financial development through economic growth. Very few studies is available on the direct relationship between FDI and financial development. To fill this research gap, we want to analyse the impact of FDI on financial development for top and bottom remittance-FDI receiving region.

Please insert Table 2 
Table 2

Literatures related to FDI-Financial Development nexus

\begin{tabular}{|c|c|c|c|c|}
\hline $\begin{array}{l}\text { Alfaro et al., } \\
(2009)\end{array}$ & $\begin{array}{l}1975- \\
1995\end{array}$ & 134 countries & Simple OLS & $\begin{array}{l}\text { Countries with well-developed } \\
\text { financial markets positively } \\
\text { affected by FDI via total factor } \\
\text { productivity enhancement. }\end{array}$ \\
\hline $\begin{array}{l}\text { Bayar \& } \\
\text { Gavriletea, } \\
(2018)\end{array}$ & $\begin{array}{l}1996- \\
2015\end{array}$ & $\begin{array}{l}\text { Central and } \\
\text { Eastern } \\
\text { European Union } \\
\text { Countries }\end{array}$ & $\begin{array}{l}\text { Westerlund-Durbin- } \\
\text { Hausman (2008) and } \\
\text { Dumitrescu and Hurlin } \\
(2012) \text {. }\end{array}$ & $\begin{array}{l}\text { In the long run no association } \\
\text { exist between FDI and financial } \\
\text { development. But a one-way } \\
\text { causal relationship observes in the } \\
\text { short run. }\end{array}$ \\
\hline $\begin{array}{l}\text { Bhattacharya } \\
\text { et al., (2018) }\end{array}$ & $\begin{array}{l}1992- \\
2012\end{array}$ & $\begin{array}{l}57 \text { highest } \\
\text { remittances } \\
\text { receiving } \\
\text { developed and } \\
\text { developing } \\
\text { countries }\end{array}$ & $\begin{array}{l}\text { Pooled Ordinary Least } \\
\text { Squares (POLS) and the } \\
\text { dynamic system } \\
\text { Generalized Method of } \\
\text { Moment (GMM) }\end{array}$ & $\begin{array}{l}\text { FDI inflows play a more significant } \\
\text { role in influence the financial } \\
\text { development. }\end{array}$ \\
\hline $\begin{array}{l}\text { Raza \& } \\
\text { Jawaid, } \\
(2014)\end{array}$ & $\begin{array}{l}2000- \\
2010\end{array}$ & $\begin{array}{l}18 \text { Asian } \\
\text { countries }\end{array}$ & $\begin{array}{l}\text { ARDL bound testing } \\
\text { cointegration approach }\end{array}$ & $\begin{array}{l}\text { Stock market capitalization has an } \\
\text { adverse impact on FDI, but it has } \\
\text { positive impact on economic } \\
\text { growth. }\end{array}$ \\
\hline $\begin{array}{l}\text { Henri et al., } \\
(2019)\end{array}$ & $\begin{array}{l}1990- \\
2016\end{array}$ & $\begin{array}{l}49 \text { African } \\
\text { countries }\end{array}$ & Panel ARDL & $\begin{array}{l}\text { FDI positively impact the financial } \\
\text { development. }\end{array}$ \\
\hline $\begin{array}{l}\text { Tsagkanos et } \\
\text { al., (2019) }\end{array}$ & $\begin{array}{l}1988- \\
2014\end{array}$ & Greece & $\begin{array}{l}\text { Markov Switching } \\
\text { regression approaches }\end{array}$ & $\begin{array}{l}\text { FDI positively impacts stock } \\
\text { market development, not the } \\
\text { banking sector. }\end{array}$ \\
\hline $\begin{array}{l}\text { Otchere et al., } \\
(2016)\end{array}$ & $\begin{array}{l}1996- \\
2009\end{array}$ & $\begin{array}{l}\text { African } \\
\text { countries }\end{array}$ & Granger causality tests & $\begin{array}{l}\text { FDI is an important factor of } \\
\text { financial development. }\end{array}$ \\
\hline $\begin{array}{l}\text { Hajilee \& } \\
\text { Nasser, } \\
(2015)\end{array}$ & $\begin{array}{l}1980- \\
2010\end{array}$ & $\begin{array}{l}\text { Latin American } \\
\text { countries }\end{array}$ & $\begin{array}{l}\text { ARDL and Granger } \\
\text { causality test }\end{array}$ & $\begin{array}{l}\text { FDI affects positively the stock } \\
\text { market development. }\end{array}$ \\
\hline
\end{tabular}

\subsection{Economic globalization-Financial development nexus}

Nowadays, developing countries are well interconnected with other countries of the world, which confirms the presence of greater globalization. This concept is proven by the study of Mishkin, (2009), who found that globalization promotes financial development by using institutional quality as a channel in developing countries. Some of the studies that have been found who are trying to prove the Mishkin hypothesis. Studies like Kandil et al., (2015); Muye \& Muye, (2017); Shahbaz et al., (2018) confirms that globalization with institutional quality can promote financial development. But one study by Nasreen et al., (2020) finds a negative impact of globalization. 
Table 3

Literatures related to Economic Globalization-financial development nexus

\begin{tabular}{|c|c|c|c|c|}
\hline $\begin{array}{l}\text { Baltagi } \\
\text { et al., } \\
(2009)\end{array}$ & $\begin{array}{l}1980- \\
2003\end{array}$ & $\begin{array}{l}\text { Developing } \\
\text { and } \\
\text { industrialized } \\
\text { countries }\end{array}$ & $\begin{array}{l}\text { GMM } \\
\text { estimation }\end{array}$ & $\begin{array}{l}\text { Globalization can affect only the banking sector's } \\
\text { development. }\end{array}$ \\
\hline $\begin{array}{l}\text { Chinn \& } \\
\text { Ito, } \\
(2006)\end{array}$ & $\begin{array}{l}1980- \\
2000\end{array}$ & 108 countries & $\begin{array}{l}\text { Regression } \\
\text { series }\end{array}$ & $\begin{array}{l}\text { Financial globalization has a growth effect on the } \\
\text { equity market through institutional quality. }\end{array}$ \\
\hline $\begin{array}{l}\text { Law et } \\
\text { al., } \\
(2014)\end{array}$ & $\begin{array}{l}1984- \\
2006\end{array}$ & $\begin{array}{l}8 \text { East Asian } \\
\text { Countries }\end{array}$ & $\begin{array}{l}\text { FMOLS } \\
\text { and DOLS }\end{array}$ & $\begin{array}{l}\text { Economic globalization positively impacted financial } \\
\text { development through the channel of institutional } \\
\text { quality. Globalization with institutional quality is more } \\
\text { effective in the stock market than in the banking } \\
\text { sector. }\end{array}$ \\
\hline $\begin{array}{l}\text { Pal \& } \\
\text { Kumar } \\
\text { Mahalik, } \\
(2020)\end{array}$ & $\begin{array}{l}1984- \\
2016\end{array}$ & $\begin{array}{l}15 \text { European } \\
\text { and Central } \\
\text { Asian region } \\
\text { and } 4 \text { South } \\
\text { Asian regions }\end{array}$ & $\begin{array}{l}\text { Panel } \\
\text { ARDL } \\
\text { model, } \\
\text { FMOLS, } \\
\text { and DOLS }\end{array}$ & $\begin{array}{l}\text { Economic globalization with the channel of } \\
\text { institutional quality enhances financial development } \\
\text { in both developing regions. }\end{array}$ \\
\hline $\begin{array}{l}\text { Shahbaz } \\
\text { et al., } \\
\text { (2017) }\end{array}$ & $\begin{array}{l}1971- \\
2013\end{array}$ & India & $\begin{array}{l}\text { The ARDL } \\
\text { model }\end{array}$ & $\begin{array}{l}\text { Overall globalization and its different forms (political, } \\
\text { social, and economic) affect financial development. }\end{array}$ \\
\hline
\end{tabular}

\section{Theoretical Framework}

The literature emphasized the relationship between remittance, FDI, and globalization with financial development through Institutional quality. Over the three decades, it has become strong enough as globalization encouraged institutional reforms that develop economic growth and development. Mishkin, (2009) proclaimed that institutions are an essential channel behind successful financial development. Formulating sound institutions is not an effortless task as it consumes lots of time, energy, and resources. Mishkin also added that no specific formula is exist for the accurate mix of institutional characteristics. Good Institutional quality generates by establishing and maintaining strong property rights, effective legal systems, and sound financial regulations. For promoting financial development in developing economies good institutional quality is much needed. By involving the lower economies in the global financial markets, the advanced countries can help them by giving the required identical incentives for customizing the developing countries to prepare the lower economy to achieve higher economic growth.

Mishkin theoretically contends that the role of financial development is vital because the Banking sector and stock market can develop the economic productivity of a country's financial system. On the other hand, Institutional quality strengthens the financial delivery system and advance the technology, reduces the cost of information; and modify the institutional-quality reforms. Because of financial liberalization in developing countries, it is expected that financial development can mobilize both savings and investment, which leads to economic growth in developing market economies.

Few researchers have favoured, and some are contradicted with Mishkin's, (2009) findings. Rousseau \& Sylla, (2007) authenticate the theory of Mishkin by proving that globalization enhances the flow of foreign capital, which helps to reduce the borrowing costs and increase the direct investments opportunities into productive 
investment products. Demetriades \& Law, (2006) also agreed with the finding of Mishkin's theory, suggests that trade openness influence the financial institutions, which leads to the growth of middle-income countries. But developing countries with low institutions quality cannot utilize the advantages of trade openness and capital inflows, and as a result, growth becomes less.

\section{Data Sources}

This study focuses on narrowing the gap in the literature by analysing the comparative empirical effect of remittance, FDI, economic globalization on financial development dynamics between two regions, namely: a top remittance and FDI receiving developing region (European and Central Asian region) and low remittance and FDI receiving developing region (Sub-Saharan African region). Additionally, this study also focuses on the impact of economic globalization on these two developing regions for 1984-2020. These two regions include 44 countries, wherefrom 15 countries are included on top remittances and FDI receiving developing region, and bottom remittances and FDI receiving developing region are having 29 countries. Both regions were included to represent the developing world better and examine the differences between the two regional groups. These specific countries were chosen based on data availability, especially for the remittance and FDI, economic globalization, and institutional quality variables.

We have taken Gygli et al., (2019) data, a newly published KOF economic globalization index dataset in the International monetary fund. Institutional quality datasets were provided by the International Country Risk Guide (ICRG), which allowed us to test the hypothesis. A total of three control variables added to the primary model have been proposed in this study: Real GDP per capita, Consumer price index (Inflation), and Gross fixed capital formation. All data are collected from the World Development Indicators and the International Monetary Fund.

Please insert Table 4 
Definition and source of variables

\begin{tabular}{|c|c|c|c|}
\hline Variables & Definition & Units & Source \\
\hline FD & Financial development index & $\begin{array}{l}\text { Index } \\
\text { value }\end{array}$ & $\begin{array}{l}\text { International } \\
\text { monetary } \\
\text { fund }\end{array}$ \\
\hline $\mathrm{FI}$ & Financial institution index & $\begin{array}{l}\text { Index } \\
\text { value }\end{array}$ & $\begin{array}{l}\text { International } \\
\text { monetary } \\
\text { fund }\end{array}$ \\
\hline FM & Financial market index & $\begin{array}{l}\text { Index } \\
\text { value }\end{array}$ & $\begin{array}{l}\text { International } \\
\text { monetary } \\
\text { fund }\end{array}$ \\
\hline LNREM & Personal remittances received (\% of GDP) & $\begin{array}{l}\text { Percentage } \\
\text { of GDP }\end{array}$ & $\begin{array}{l}\text { World } \\
\text { Development } \\
\text { Indicators }\end{array}$ \\
\hline LNFDI & Foreign direct investment, net inflows (\% of GDP) & $\begin{array}{l}\text { Percentage } \\
\text { of GDP }\end{array}$ & $\begin{array}{l}\text { World } \\
\text { Development } \\
\text { Indicators }\end{array}$ \\
\hline LNEGLOB & KOF Economic Globalization index & $\begin{array}{l}\text { Index } \\
\text { value }\end{array}$ & $\begin{array}{l}\text { International } \\
\text { monetary } \\
\text { fund (Gygli } \\
\text { et al., 2019) }\end{array}$ \\
\hline IQ & $\begin{array}{l}\text { An institutional quality index (combining all the variables like } \\
\text { Government Stability, Socioeconomic Conditions, Investment } \\
\text { Profile, Internal Conflict, External Conflict, Corruption, Military in } \\
\text { Politics, Religious Tensions, Law and Order, Ethnic Tensions, } \\
\text { Democratic Accountability, Bureaucracy Quality and make one } \\
\text { index term by PCA) }\end{array}$ & $\begin{array}{l}\text { Index } \\
\text { value }\end{array}$ & $\begin{array}{l}\text { International } \\
\text { Country Risk } \\
\text { Guide }\end{array}$ \\
\hline LNGDP & GDP per capita & $\begin{array}{l}\text { Per capita } \\
\text { as per } \\
\text { constant } \\
2010 \text { US\$ }\end{array}$ & $\begin{array}{l}\text { World } \\
\text { Development } \\
\text { Indicators }\end{array}$ \\
\hline INF & Inflation (GDP deflator) & $\begin{array}{l}\text { Annual } \\
\text { percentage }\end{array}$ & $\begin{array}{l}\text { World } \\
\text { Development } \\
\text { Indicators }\end{array}$ \\
\hline LNGFCF & Gross fixed capital formation & $\begin{array}{l}\text { Percentage } \\
\text { of GDP }\end{array}$ & $\begin{array}{l}\text { International } \\
\text { monetary } \\
\text { fund }\end{array}$ \\
\hline
\end{tabular}

\section{Methodology}

The purpose of estimating plan of action is to explain the relationship between financial development, and remittance, FDI as well as economic globalization through some control variables, like, institutional quality, economic growth, inflation, and domestic investment (Gross fixed capital formation), by employing an empirical model that enables the possibility of testing the hypothesis of this study. The general forms of financial development, financial institution, and financial market with the presence of economic globalization backed by 
institutional quality with other control variables for developing countries are constructed based on our previous discussion, as follows:

\section{MODEL 1A}

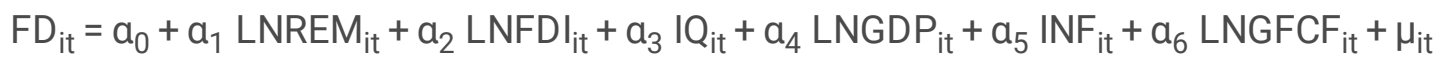

\section{MODEL 1B}

$\mathrm{FD}_{\text {it }}=\mathrm{a}_{0}+\mathrm{a}_{1} \mathrm{LNEGLOB}_{\mathrm{it}}+\mathrm{a}_{2}$ INSQ $_{i \mathrm{t}}+\mathrm{a}_{3}$ LNGDP $_{\mathrm{it}}+\mathrm{a}_{4} \mathrm{INF}_{\mathrm{it}}+\mathrm{a}_{5} \mathrm{LNGFCF}_{\mathrm{it}}+\mu_{\mathrm{it}}$

\section{MODEL 2A}

$\mathrm{Fl}_{\mathrm{it}}=\mathrm{a}_{0}+\mathrm{a}_{1}$ LNREM $_{\mathrm{it}}+\mathrm{a}_{2}$ LNFDI $_{\mathrm{it}}+\mathrm{a}_{3} \mathrm{IQ}_{\mathrm{it}}+\mathrm{a}_{4} \mathrm{LNGDP}_{\mathrm{it}}+\mathrm{a}_{5} \mathrm{INF}_{\mathrm{it}}+\mathrm{a}_{6} \mathrm{LNGFCF}_{\mathrm{it}}+\mu_{\mathrm{it}}$

\section{MODEL 2B}

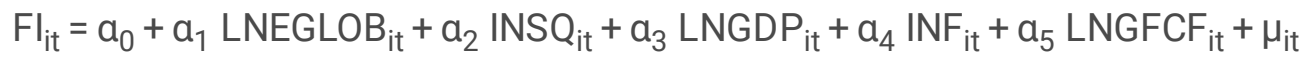

\section{MODEL 3A}

$\mathrm{FM}_{\mathrm{it}}=\mathrm{a}_{0}+\mathrm{a}_{1}$ LNREM $_{\mathrm{it}}+\mathrm{a}_{2} \mathrm{LNFDI}_{\mathrm{it}}+\mathrm{a}_{3} \mathrm{IQ}_{\mathrm{it}}+\mathrm{a}_{4} \mathrm{LNGDP}_{\mathrm{it}}+\mathrm{a}_{5} \mathrm{INF}_{\mathrm{it}}+\mathrm{a}_{6} \mathrm{LNGFCF}_{\mathrm{it}}+\mu_{\mathrm{it}}$

\section{MODEL 3B}

$\mathrm{FM}_{\mathrm{it}}=\mathrm{a}_{0}+\mathrm{a}_{1} \mathrm{LNEGLOB}_{\text {it }}+\mathrm{a}_{2}$ INSQ $_{\text {it }}+\mathrm{a}_{3} \mathrm{LNGDP}_{\mathrm{it}}+\mathrm{a}_{4} \mathrm{INF}_{\text {it }}+\mathrm{a}_{5} \mathrm{LNGFCF}_{\text {it }}+\mu_{\text {it }}$

Where dependent variables of these equations are $\mathrm{FD}_{\mathrm{it}}, \mathrm{Fl}_{\mathrm{it}}$, and $\mathrm{FM}_{\mathrm{it}}$, which represent the financial development index, financial institution index, and financial market index, respectively. Independent variables are REM $\mathrm{it}_{\mathrm{it}}$, and $F D I_{i t}$ represents the remittance received and FDI inflows. LNEGLOB ${ }_{\text {it }}$ represents KOF economic globalization index. Lastly, other control variables are INSQ ${ }_{i t}, \mathrm{LNGDP}_{\mathrm{it}}, \mathrm{INF}_{\mathrm{it}}$, and $\mathrm{GFCF}_{i t}$ represent an institutional quality index, gross domestic product per capita, inflation, and gross fixed capital formation. $\mu_{i t}$ represents an independent and identical error term.

In literature, different estimators are available to estimate vectoring Co-integration panel data, including with and between groups such as Ordinary least square (OLS), fully modified OLS (FMOLS) estimators, and dynamic OLS (DOLS) estimators, etc. This study uses two methods, FMOLS and DOLS to estimate the long-term relationship between the variables. These two methods allow the null hypothesis to test a strong relationship between financial development, financial institution, and market, Remittance and FDI, Economic globalization, Institutional quality, GDP per capita, Inflation, and Gross fixed capital formation for the two regions developing countries.

To test the null hypothesis between-dimension estimators are constructed as $\mathrm{H}_{0}: \beta_{\mathrm{i}}=\beta_{0}$ for all $i$ against the alternative $H_{1}: \beta_{i} \neq \beta_{0}$, so that the values for $\beta_{i}$ are not constrained to be the same under the alternative hypothesis. Considering the following cointegrated system for a panel of $i=1 \ldots N$ members we get

$Y_{i t}=a_{i}+\beta x_{i t}+u_{i t}$ for $i=1 \ldots N$ and $t=1 \ldots . T(9)$ 
$x_{i t}=x_{i t-1}+e_{i t}(10)$

Where $Y_{i t}$ is a matrix $(1 \times 1), a_{i}$ is the individual fixed effect, $\beta$ is a vector of slopes $(k \times 1)$ dimension, $x_{i t}$ is a vector $(k \times 1)$ dimension.

$Z_{i t}=\left(Y_{i t}, x_{i t}\right)^{\prime} \rightarrow I(1) \Xi_{i t}=\left(u_{i t}, e_{i t}\right)^{\prime} \rightarrow I(0)$

In this paper, we consider the FMOLS methodology developed by (Kao \& Chiang, 2001). These estimators help to calculate the long run cointegration vector for non-stationary panels. They both are asymptotically normal for examining the limited distribution. The FMOLS is more modified as it corrected the errors of endogeneity and serial correlation to the OLS estimator, and it is defined as:

$\widehat{\beta}_{\mathrm{FM}}=\left[\sum_{\mathrm{i}=1}^{\mathrm{N}} \sum_{\mathrm{t}=1}^{\mathrm{T}}\left(\mathrm{x}_{\mathrm{it}}-\overline{\mathrm{x}}_{\mathrm{i}}\right)\left(\mathrm{x}_{\mathrm{it}}-\overline{\mathrm{x}}_{\mathrm{i}}\right) /\right]^{-1}\left[\sum_{\mathrm{i}=1}^{\mathrm{N}}\left(\sum_{\mathrm{t}=1}^{\mathrm{T}}\left(\mathrm{x}_{\mathrm{it}}-\overline{\mathrm{x}}_{\mathrm{i}}\right) \widehat{\mathrm{Y}}_{\mathrm{it}}^{*}+\widehat{\mathrm{T}}_{\mathrm{EM}}^{*}\right)\right]$

$\widehat{\mathrm{Y}_{\mathrm{it}}^{*}}$ is the transformed variable of $\mathrm{Y}_{\mathrm{it}}$ to correct the endogeneity errors, where $\left(\widehat{\mathrm{Y}_{\mathrm{it}}^{*}}=\mathrm{Yit}-\widehat{\Omega_{\mathrm{EM}}} \widehat{\Omega_{\mathrm{E}}^{-1}} \Delta \mathrm{x}_{\mathrm{it}}\right)$, and $\widehat{\Delta}_{\mathrm{EM}}^{*}$ is the serial correlation error term, where $\left(\widehat{\Delta}_{\mathrm{EM}}^{*}=\widehat{\Delta}_{\mathrm{EM}}-\widehat{\Delta}_{\mathrm{E}} \widehat{\Omega_{\mathrm{EM}}} \widehat{\Omega_{\mathrm{E}}^{-1}}\right)$.

The error of serial correlation and endogeneity can be removed by using the DOLS estimator, developed by (Stock \& Watson, 1993) estimator. The DOLS estimator is obtained from the following equation:

$Y_{i t}=a_{i}+\beta x_{i t}+\sum_{j=q_{1}}^{j=q_{2}} C_{i j} \Delta x_{i, t-j}+V_{i t}$

$\mathrm{C}_{\mathrm{ij}}$ is the coefficient of a lead or lag of the first differenced explanatory variables. The estimated coefficient of DOLS is given from the following equation:

$$
\widehat{\beta}_{\text {DOLS }}=\left[\sum_{\mathrm{i}=1}^{\mathrm{N}} \sum_{\mathrm{i}=1}^{\mathrm{T}} \mathrm{q}_{\mathrm{it}} \mathrm{q}_{\mathrm{it}} /\right]^{-1}\left[\sum_{\mathrm{i}=1}^{\mathrm{N}} \sum_{\mathrm{i}=1}^{\mathrm{T}} \mathrm{q}_{\mathrm{it}} \widehat{\mathrm{Y}_{\mathrm{it}}^{*}}\right]
$$

Where $q_{i j}$ is $2(q+1)$ vectors of regressors.

\section{Result And Discussion}

In this section, we discuss the empirical results and discussion. Firstly, we estimate the stationary property of the variables using both first and second-generation panel unit root tests. Under the first generation panel unit root test, we uses IPS (Im et al., 2003) which performs both at levels and first differences of each variable. The unit root results are mixed order of integration with I (0) and I (1).

Please insert Table 5 
Table 5

Conventional Unit-root test (Im-Pesaran-Shin unit root test)

\begin{tabular}{|c|c|c|c|c|c|}
\hline \multirow[t]{2}{*}{ Variables } & \multicolumn{2}{|c|}{ Europe And Central Asian Region } & \multicolumn{3}{|c|}{ Sub-Saharan African Region } \\
\hline & Level & Inference & Level & First Difference & Inference \\
\hline FD & 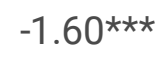 & $\mathrm{I}(0)$ & $-5.50 \star$ & & $\mathrm{I}(0)$ \\
\hline $\mathrm{FI}$ & $-2.80 *$ & $\mathrm{I}(0)$ & $-2.22^{\star \star}$ & & $\mathrm{I}(0)$ \\
\hline FM & $-4.02 *$ & $\mathrm{I}(0)$ & 1.77547 & $-1.89 * *$ & $\mathrm{I}(1)$ \\
\hline LNEGLOB & $-4.05^{\star}$ & $\mathrm{I}(0)$ & $-3.45^{\star}$ & & $\mathrm{I}(0)$ \\
\hline LNREM & 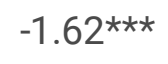 & $\mathrm{I}(0)$ & $-2.68^{\star}$ & & $\mathrm{I}(0)$ \\
\hline LNFDI & -2.24 *夫 & $\mathrm{I}(0)$ & $-6.30 \star$ & & $\mathrm{I}(0)$ \\
\hline IQ & $-3.16^{\star}$ & $\mathrm{I}(0)$ & $-7.09 *$ & & $\mathrm{I}(0)$ \\
\hline LNGDP & $-1.68^{\star \star}$ & $\mathrm{I}(0)$ & $-7.08 *$ & & $\mathrm{I}(0)$ \\
\hline INF & $-5.60 *$ & $\mathrm{I}(0)$ & $-6.93^{*}$ & & $\mathrm{I}(0)$ \\
\hline LNGFCF & $-2.02 * \star$ & $\mathrm{I}(0)$ & $-3.65^{\star}$ & & $\mathrm{I}(0)$ \\
\hline
\end{tabular}

The drawback of the IPS panel unit root is that it does not consider cross-sectional dependence and heterogeneity issues of the first-order autoregressive parameters across the cross-countries from the panels. To modify this issue, we again check the unit root test of the variables by applying cross-sectional IPS (CIPS) (Pesaran, 2007).

Please insert Table 6 -_-_ 
Table 6

Second-generation Unit-root test (Cross-sectional Im-Pesaran-Shin unit root test)

\begin{tabular}{|c|c|c|c|c|c|c|c|c|}
\hline \multirow[t]{3}{*}{ Variables } & \multicolumn{4}{|c|}{ Europe And Central Asian Region } & \multicolumn{4}{|c|}{ Sub-Saharan African Region } \\
\hline & \multicolumn{2}{|l|}{ Level } & \multicolumn{2}{|c|}{ First Difference } & \multicolumn{2}{|l|}{ Level } & \multicolumn{2}{|c|}{ First Difference } \\
\hline & Constant & $\begin{array}{l}\text { Constant } \\
\text { and } \\
\text { Trend }\end{array}$ & Constant & $\begin{array}{l}\text { Constant } \\
\text { and } \\
\text { Trend }\end{array}$ & Constant & $\begin{array}{l}\text { Constant } \\
\text { and } \\
\text { Trend }\end{array}$ & Constant & $\begin{array}{l}\text { Constant } \\
\text { and } \\
\text { Trend }\end{array}$ \\
\hline FD & $-3.28 *$ & $-3.14^{\star}$ & $-5.63^{\star}$ & $-5.77 \star$ & $-2.36^{\star}$ & -2.39 & $-5.58^{\star}$ & $-5.76^{\star}$ \\
\hline $\mathrm{FI}$ & $-3.35^{\star}$ & $-3.19 *$ & $-5.64^{\star}$ & $-5.82^{\star}$ & $-2.23^{\star}$ & -2.48 & $-5.51^{\star}$ & $-5.64^{\star}$ \\
\hline FM & -2.39 & -2.57 & $-5.37 *$ & $-5.37 \star$ & -1.62 & -1.65 & $-4.02^{\star}$ & $-4.43^{\star}$ \\
\hline LNEGLOB & $-3.12^{\star}$ & $-3.13^{\star}$ & $-5.20 \star$ & $-5.09 *$ & $-2.23^{\star}$ & $-2.42^{\star}$ & $-5.50 \star$ & $-5.64^{\star}$ \\
\hline LNREM & $-2.57 *$ & $-3.37 \star$ & $-5.24 *$ & $-5.36^{\star}$ & $-2.19 *$ & $-3.15^{\star}$ & $-5.32 \star$ & $-5.44^{\star}$ \\
\hline LNFDI & $-3.59 \star$ & $-3.75^{\star}$ & $-5.55^{\star}$ & $-5.60 *$ & $-3.55^{\star}$ & $-3.87^{\star}$ & $-5.81^{\star}$ & $-5.95^{\star}$ \\
\hline IQ & $-2.26 * \star$ & $-3.23^{\star}$ & $-5.05^{\star}$ & $-4.86^{\star}$ & $-3.28 *$ & $-3.26^{\star}$ & $-5.49 \star$ & $-5.50 *$ \\
\hline LNGDP & -2.02 & 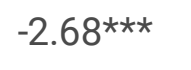 & $-5.06^{\star}$ & $-5.02^{\star}$ & $-2.69 *$ & $-2.99 *$ & $-5.33^{\star}$ & $-5.45^{\star}$ \\
\hline INF & $-4.39 *$ & $-4.34^{\star}$ & $-5.69 *$ & $-5.78^{\star}$ & $-5.48^{\star}$ & $-5.55^{\star}$ & $-6.06^{\star}$ & $-6.23^{\star}$ \\
\hline LNGFCF & $2.57^{\star}$ & $-2.93^{*}$ & $-4.98^{*}$ & $-4.97^{\star}$ & $-2.69 *$ & $-3.40 *$ & $-5.43^{\star}$ & $-5.44^{\star}$ \\
\hline
\end{tabular}

We confirm heterogeneity and spatial effect across the panel of 44 developing countries by using the crosssectional dependency and slope homogeneity test (Table 7). We have checked the cross-sectional dependence issue among the variables by using three different CD approaches, namely Pesaran CD, Pesaran scaled LM, Breusch-Pagan LM tests. The null hypothesis $(\mathrm{HO})$ of no cross-sectional independence between countries is not accepted in all the tests. It displays that shock in one country will affect the other country also. Because of this cause, the traditional unit root test becomes invalid for the assumption of cross-sectional independence. Therefore the present study applies cross-sectional augmented IPS (CIPS) tests developed by Pesaran, (2007) to overcome this problem. The CIPS test applies under the assumption that variables are cross-sectional dependent. Finally, our unit root test result show that all the variables have unit roots mainly at constant and trend. The panel unit root test concludes that the variables are non-stationary at level, which signals the panel cointegration test. 
Table 7

Cross-sectional dependence test

\section{Europe and Central Asian Region Sub-Saharan African Region}

MODEL 1A: FD = f(LNREM, LNFDI, IQ, LNGDP, INF, LNGFCF)

\begin{tabular}{|lll}
\hline Breusch-Pagan LM & $767.63^{*}$ & $2697.40^{\star}$ \\
\hline Pesaran scaled LM & $45.72^{\star}$ & $80.41^{\star}$ \\
\hline Pesaran CD & $13.27 \star$ & $11.26^{\star}$ \\
\hline MODEL 1B: FD = f(LNEGLOB, IQ, LNGDP, INF, LNGFCF) & \\
\hline Breusch-Pagan LM & $755.82^{\star}$ & $2746.06^{\star}$ \\
\hline Pesaran scaled LM & $44.91^{\star}$ & $82.12^{\star}$ \\
\hline Pesaran CD & $8.76^{\star}$ & $11.88^{\star}$
\end{tabular}

MODEL 2A: FI = f(LNREM, LNFDI, IQ, LNGDP, INF, LNGFCF)

\begin{tabular}{|lll|}
\hline Breusch-Pagan LM & 823.71* & $2800.45^{\star}$ \\
\hline Pesaran scaled LM & $49.59 *$ & $84.02^{\star}$ \\
\hline Pesaran CD & $9.91^{\star}$ & $7.06 *$
\end{tabular}

MODEL 2B: FI = f(LNEGLOB, IQ, LNGDP, INF, LNGFCF)

\begin{tabular}{lll} 
Breusch-Pagan LM & $847.76^{*}$ & $2791.21 *$ \\
\hline Pesaran scaled LM & $51.25^{\star}$ & $83.70 \star$ \\
\hline Pesaran CD & $7.38 *$ & $6.99 *$
\end{tabular}

MODEL 3A: FM = f(LNREM, LNFDI, IQ, LNGDP, INF, LNGFCF)

\begin{tabular}{|c|c|c|}
\hline Breusch-Pagan LM & $709.15^{\star}$ & $3061.03 *$ \\
\hline Pesaran scaled LM & $41.69 *$ & $93.17 *$ \\
\hline Pesaran CD & $10.27^{\star}$ & $23.64 *$ \\
\hline \multicolumn{3}{|c|}{ MODEL 3B: FM = f(LNEGLOB, IQ, LNGDP, INF, LNGFCF) } \\
\hline Breusch-Pagan LM & $790.78 *$ & $3848.70 *$ \\
\hline Pesaran scaled LM & $47.32^{\star}$ & $120.81^{\star}$ \\
\hline Pesaran CD & $12.06^{*}$ & $23.67 \star$ \\
\hline
\end{tabular}

Please insert Table 7

Next, we test whether there is cointegration between the variables by using (Pedroni, 2004) and Westerlund, (2012) panel cointegration tests for both regions. The results obtained from the cointegration test conclude a long-run relationship between financial development with remittance, FDI, and economic globalization. 
Please insert Table 8

Page 17/32 
Table 8

Pedroni and Westerlund panel cointegration test

\section{Pedroni panel cointegration \\ Westerlund panel cointegration}

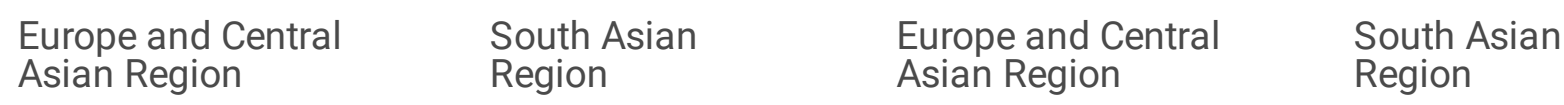

MODEL 1A: FD = f(LNREM, LNFDI, IQ, LNGDP, INF, LNGFCF)

\begin{tabular}{|c|c|c|c|c|c|}
\hline $\begin{array}{l}\text { Panel v- } \\
\text { Statistic }\end{array}$ & $3.74^{*}$ & -2.28 & Gt & $-2.49 *$ & $-2.51^{\star}$ \\
\hline $\begin{array}{l}\text { Panel rho- } \\
\text { Statistic }\end{array}$ & 7.16 & 10.45 & $\mathrm{Ga}$ & $-6.16^{\star}$ & $-10.72^{*}$ \\
\hline $\begin{array}{l}\text { Panel PP- } \\
\text { Statistic }\end{array}$ & $-4.12^{\star}$ & $-10.20 *$ & $\mathrm{Pt}$ & $-8.29 *$ & $-10.62^{*}$ \\
\hline $\begin{array}{l}\text { Panel ADF- } \\
\text { Statistic }\end{array}$ & 6.56 & 11.04 & $\mathrm{~Pa}$ & $-5.34^{\star}$ & -8.01 \\
\hline $\begin{array}{l}\text { Group rho- } \\
\text { Statistic }\end{array}$ & 8.61 & 11.74 & & & \\
\hline $\begin{array}{l}\text { Group PP- } \\
\text { Statistic }\end{array}$ & $-11.38 *$ & $-74.95^{\star}$ & & & \\
\hline $\begin{array}{l}\text { Group ADF- } \\
\text { Statistic }\end{array}$ & $-6.70 *$ & $-10.34 *$ & & & \\
\hline
\end{tabular}

MODEL 1B: FD = f(LNEGLOB, IQ, LNGDP, INF, LNGFCF)

$\begin{array}{llllll}\text { Panel v- } & 0.74 & -6.43 & \text { Gt } & -3.15^{*} & -2.33^{*}\end{array}$

Statistic
Panel rho-
5.79
6.17
$\mathrm{Ga} \quad-5.32 *$
$-9.74^{*}$

Statistic

Panel PP-

$-10.06 *$

$-4.09 *$

Pt $\quad-10.18^{\star}$

$-8.97 *$

Statistic

Panel ADF

7.16

$-2.60 *$

$\mathrm{Pa} \quad-5.19$

$-5.81$

Statistic

Group rho-

7.38

10.28

Statistic

Group PP-

$-16.77^{*}$

$-15.24^{*}$

Statistic

$-23.71 *$

$-70.60 *$

Group ADF-

Statistic

MODEL 2A: FI = f(LNREM, LNFDI, IQ, LNGDP, INF, LNGFCF)

$\begin{array}{llllll}\text { Panel v- } & 10.37^{*} & -3.39 & \text { Gt } & -2.16 & -2.61^{*}\end{array}$

Statistic 
Pedroni panel cointegration

\begin{tabular}{|c|c|c|c|c|c|}
\hline $\begin{array}{l}\text { Panel rho- } \\
\text { Statistic }\end{array}$ & 7.63 & 8.47 & $\mathrm{Ga}$ & $-4.36^{\star}$ & $-11.77^{\star}$ \\
\hline $\begin{array}{l}\text { Panel PP- } \\
\text { Statistic }\end{array}$ & $-6.52^{\star}$ & $-1.90 *$ & $\mathrm{Pt}$ & $-8.39 *$ & $-11.27^{\star}$ \\
\hline $\begin{array}{l}\text { Panel ADF- } \\
\text { Statistic }\end{array}$ & 7.27 & 8.03 & $\mathrm{~Pa}$ & $-4.13^{\star}$ & -8.05 \\
\hline $\begin{array}{l}\text { Group rho- } \\
\text { Statistic }\end{array}$ & 8.85 & 9.75 & & & \\
\hline $\begin{array}{l}\text { Group PP- } \\
\text { Statistic }\end{array}$ & $-21.93^{\star}$ & $-113.87 *$ & & & \\
\hline $\begin{array}{l}\text { Group ADF- } \\
\text { Statistic }\end{array}$ & 4.34 & $-44.44^{\star}$ & & & \\
\hline
\end{tabular}

MODEL 2B: FI = f(LNEGLOB, IQ, LNGDP, INF, LNGFCF)

\begin{tabular}{llllll}
$\begin{array}{l}\text { Panel v- } \\
\text { Statistic }\end{array}$ & $7.88^{\star}$ & $8.50^{\star}$ & Gt & $-2.95^{\star}$ & $-2.29^{\star}$ \\
$\begin{array}{l}\text { Panel rho- } \\
\text { Statistic }\end{array}$ & 6.82 & 9.27 & Ga & $-4.57^{\star}$ & $-9.68^{\star}$ \\
$\begin{array}{l}\text { Panel PP- } \\
\text { Statistic }\end{array}$ & $-5.86^{\star}$ & -0.86 & Pt & $-9.67^{\star}$ & $-9.61^{\star}$ \\
$\begin{array}{l}\text { Panel ADF- } \\
\text { Statistic }\end{array}$ & 10.43 & $-2.14^{\star *}$ & Pa & $-3.32^{\star}$ & \\
$\begin{array}{l}\text { Group rho- } \\
\text { Statistic }\end{array}$ & 7.82 & 11.17 & & & $-6.59^{\star}$ \\
$\begin{array}{l}\text { Group PP- } \\
\text { Statistic }\end{array}$ & $-37.40^{\star}$ & $-144.17^{\star}$ & & & \\
$\begin{array}{l}\text { Group ADF- } \\
\text { Statistic }\end{array}$ & 2.62 & $-39.67^{\star}$ & & & \\
\hline
\end{tabular}

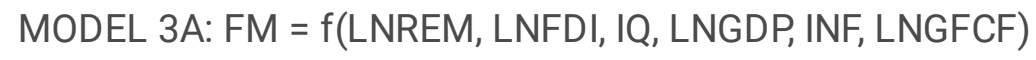

\begin{tabular}{llllll}
$\begin{array}{l}\text { Panel v- } \\
\text { Statistic }\end{array}$ & -5.21 & -4.47 & Gt & -2.60 & $-1.41^{\star}$ \\
$\begin{array}{l}\text { Panel rho- } \\
\text { Statistic }\end{array}$ & 7.20 & 7.89 & Ga & $-7.08^{*}$ & $-1.50^{\star}$ \\
$\begin{array}{l}\text { Panel PP- } \\
\text { Statistic }\end{array}$ & $-9.03^{\star}$ & $-15.84^{\star}$ & Pt & $-9.61^{\star}$ & $-6.20^{\star}$ \\
$\begin{array}{l}\text { Panel ADF- } \\
\text { Statistic }\end{array}$ & $-3.63^{*}$ & $-1.32^{\star * *}$ & Pa & $-6.53^{*}$ & $-1.25^{\star}$ \\
$\begin{array}{l}\text { Group rho- } \\
\text { Statistic }\end{array}$ & 8.37 & 9.30 & & & \\
\hline
\end{tabular}




\begin{tabular}{|c|c|c|c|c|c|}
\hline \multirow[b]{2}{*}{$\begin{array}{l}\text { Group PP- } \\
\text { Statistic }\end{array}$} & \multicolumn{2}{|c|}{ Pedroni panel cointegration } & \multicolumn{3}{|c|}{ Westerlund panel cointegration } \\
\hline & $-8.99 *$ & $-166.01^{\star}$ & & & \\
\hline $\begin{array}{l}\text { Group ADF- } \\
\text { Statistic }\end{array}$ & $-18.54^{\star}$ & $-4.45^{\star}$ & & & \\
\hline \multicolumn{6}{|c|}{ MODEL 3B: FM = f(LNEGLOB, IQ, LNGDP, INF, LNGFCF) } \\
\hline $\begin{array}{l}\text { Panel v- } \\
\text { Statistic }\end{array}$ & $8.10^{*}$ & $3.32^{\star}$ & Gt & $-2.55^{\star}$ & $-1.83^{\star}$ \\
\hline $\begin{array}{l}\text { Panel rho- } \\
\text { Statistic }\end{array}$ & 6.22 & 7.17 & $\mathrm{Ga}$ & -4.96 & $-10.35^{\star}$ \\
\hline $\begin{array}{l}\text { Panel PP- } \\
\text { Statistic }\end{array}$ & $-24.92^{\star}$ & $-3.78^{\star}$ & Pt & $-9.78^{*}$ & $-9.87 \star$ \\
\hline $\begin{array}{l}\text { Panel ADF- } \\
\text { Statistic }\end{array}$ & 3.31 & 1.07 & $\mathrm{~Pa}$ & $-5.74^{\star}$ & $-9.53^{\star}$ \\
\hline $\begin{array}{l}\text { Group rho- } \\
\text { Statistic }\end{array}$ & 7.65 & 9.81 & & & \\
\hline $\begin{array}{l}\text { Group PP- } \\
\text { Statistic }\end{array}$ & $-38.62^{\star}$ & $-32.27 *$ & & & \\
\hline $\begin{array}{l}\text { Group ADF- } \\
\text { Statistic }\end{array}$ & $-16.55^{\star}$ & $-39.32^{\star}$ & & & \\
\hline
\end{tabular}


Table 9

A. Fully modified ordinary least square (FMOLS) and Dynamic least squares (DOLS)

\begin{tabular}{|lllll} 
Variables & \multicolumn{2}{l}{ Europe And Central Asian Region } & \multicolumn{2}{l}{ Sub-Saharan African Region } \\
\cline { 2 - 5 } & $\begin{array}{lll}\text { Fully Modified Ordinary } \\
\text { Least Square (FMOLS) }\end{array}$ & $\begin{array}{l}\text { Dynamic Ordinary } \\
\text { Least Square } \\
\text { (DOLS) }\end{array}$ & $\begin{array}{l}\text { Fully Modified Ordinary } \\
\text { Least Square (FMOLS) }\end{array}$ & $\begin{array}{l}\text { Dynamic Ordinary } \\
\text { Least Square } \\
\text { (DOLS) }\end{array}$ \\
\hline
\end{tabular}

MODEL 1A: FD = f(LNREM, LNFDI, IQ, LNGDP, INF, LNGFCF $)$

\begin{tabular}{|c|c|c|c|c|}
\hline LNREM & $0.026^{*}$ & $0.003^{*}$ & $0.000^{*}$ & $0.000^{*}$ \\
\hline LNFDI & $0.001^{*}$ & $0.005^{\star}$ & $0.000^{*}$ & $4.98 \mathrm{E}-05^{\star}$ \\
\hline IQ & $0.019 *$ & $0.022^{*}$ & $-0.000^{*}$ & $-0.001^{*}$ \\
\hline LNGDP & $0.001 *$ & $0.083^{*}$ & $0.007 *$ & $0.012^{*}$ \\
\hline INF & $-0.000 *$ & $-3.42 \mathrm{E}-05^{\star}$ & 1.49E-06* & $7.06 \mathrm{E}-06^{*}$ \\
\hline LNGFCF & $0.006^{*}$ & $0.003^{*}$ & $0.000^{*}$ & $0.000 *$ \\
\hline \multicolumn{5}{|c|}{ MODEL 1B: FD = f(LNEGLOB, IQ, LNGDP, INF, LNGFCF) } \\
\hline LNEGLOB & $0.127 *$ & $0.005^{\star}$ & $0.006^{*}$ & $0.005^{\star}$ \\
\hline IQ & $0.010^{\star}$ & $0.022^{*}$ & $0.002^{\star}$ & $0.000^{\star}$ \\
\hline LNGDP & $0.103^{*}$ & $0.042^{\star}$ & $0.000^{\star}$ & $0.028^{\star}$ \\
\hline INF & $-0.000 *$ & $-3.28 \mathrm{E}-05^{*}$ & $-2.36 \mathrm{E}-05^{\star}$ & $-3.99 \mathrm{E}-06 *$ \\
\hline LNGFCF & $0.004^{*}$ & $0.003^{*}$ & $0.000^{*}$ & $0.000^{*}$ \\
\hline
\end{tabular}

Finally, we have done the fully modified OLS and dynamic OLS to find the variables' long-run relationship empirically. Table 9A illustrates the determinants of financial development by examining the impact of remittance, FDI, and economic globalization and by taking institutional quality, GDP per capita, inflation, and domestic investment as the additional control variables (Model 1A). Results show that remittance is positively affecting financial development in both the region (Aggarwal et al., 2011; Coulibaly, 2015), but the coefficient of remittances is higher in the ECA region (Basnet et al., 2021) than the Sub Saharan Africa region (Bolarinwa \& Akinbobola, 2021). This result is evident, as the ECA region is the top remittance-receiving region and the SSA region is the bottom one. Oppositely, the same result we are getting in the case of FDI, where the coefficient is also high in the top FDI receiving region than the bottom one. This positive impact of FDI is also getting by some studies like Ang, (2009) and Majeed et al., (2021). Institutional quality is behaving like a channel of remittance and FDI inflows as they positively impact financial development in both regions, which is supported the hypothesis of Mishkin, (2009). Economic growth (De Gregorio \& Guidotti, 1995) and government investment (Nazlioglu et al., 2009) positively and significantly impact financial development. Domestic investment can increase the per capita income, which automatically enhances the purchasing power and demand of the consumers. Whereas capital accumulation also enhances the productions and productivity as capital flows will increase, which leads to higher economic growth and better financial development. On the other hand, inflation is 
negatively impacting financial development in ECA region but positively impacting in SSA region. Lower Inflation enhances employment as consumers having more purchasing power which increases the economic benefit and growth.

This result is the same for the economic globalization-financial development nexus (Model 1B). Economic globalization positively affects both regions (Pal \& Kumar Mahalik, 2020); the coefficient is also higher in the ECA region than in the SSA region. These findings are also supported by Chen \& Emile, (2013); Law et al., (2014); Muye \& Muye, (2017); Shahbaz et al., (2018). The higher coefficient in top remittance and FDI receiving region is happening because of the heterogeneous growth of economic globalization. Participation of the foreign firms with a channel of developed institutional quality can enhance the competitive nature among the financial institution and market, which leads to a constant improvement of growth and development.

Please insert Table 9A

The result of Model 2A indicated a long-run relationship between the financial institution and remittance, FDI with other control variables (Table 8B). It shows a positive and significant relation between remittance and financial institutions for both the region (Ikpesu et al., 2020), but FDI is positively affecting the SSA region and negatively affecting the ECA region. However, the coefficient of remittance is higher in the ECA region than SSA region. The result signifies that both regions are interested in investing their remittance amount into the banking sector for their investment purpose. At the same time, FDI is helping as an essential catalyst in the SSA region by stimulating domestic investment, exchange rate stability, and enhancing competition. But it does not work well in the case of the ECA region. Institutional quality is a fantastic channel of remittance as it behaves the same with remittances, agreed with Mishkin, (2009). As a result, remittance with improved institutional quality can flourish the region's banking sector more efficiently and effectively.

The association between the financial institution and economic globalization is represented in Model 2B. The results show an adverse effect of economic globalization on financial development in the ECA region, but it has a positive effect in the SSA region, which is consistent with the study of Pal \& Kumar Mahalik, (2020). The top remittance-receiving region needs to focus critically on the adverse effect of economic globalization with a negative institutional quality. Our analysis confirms that the degradation of financial regulatory is one of the main reasons for damaging economic globalization. Both the regions also facing higher inflation rates that mean they will affect by lower bank credit multiplier. This may be another reason for the adverse relation between globalization and banking sector development. Domestic investment is lesser in the ECA region as their government is more concerned about other developmental works rather than globalization-related issues. In summary, we can suggest that the ECA region should follow some monetary and fiscal policy by which they can reduce the inflation rate, enhance domestic investment and make a sound financial regulatory framework, which combinedly gives the positive impact of economic globalization on the banking sector development.

Please insert Table 9B

\section{Table 9B. Fully modified ordinary least square (FMOLS) and Dynamic least squares (DOLS)}




\begin{tabular}{|c|c|c|c|c|}
\hline \multirow[t]{2}{*}{ Variables } & \multicolumn{2}{|c|}{ Europe And Central Asian Region } & \multicolumn{2}{|c|}{ Sub-Saharan African Region } \\
\hline & $\begin{array}{l}\text { Fully Modified Ordinary } \\
\text { Least Square (FMOLS) }\end{array}$ & $\begin{array}{l}\text { Dynamic Ordinary } \\
\text { Least Square } \\
\text { (DOLS) }\end{array}$ & $\begin{array}{l}\text { Fully Modified Ordinary } \\
\text { Least Square (FMOLS) }\end{array}$ & $\begin{array}{l}\text { Dynamic Ordinary } \\
\text { Least Square } \\
\text { (DOLS) }\end{array}$ \\
\hline \multicolumn{5}{|c|}{ MODEL 2A: FI = f(LNREM, LNFDI, IQ, LNGDP, INF, LNGFCF) } \\
\hline LNREM & $0.141^{*}$ & $0.029 *$ & $0.052^{\star}$ & $0.032^{\star}$ \\
\hline LNFDI & $-0.040 *$ & $-0.003^{\star}$ & $0.010^{\star}$ & $0.009 *$ \\
\hline IQ & $0.170^{\star}$ & $0.016^{*}$ & $0.006^{*}$ & $0.005^{\star}$ \\
\hline LNGDP & $0.093^{*}$ & $0.087^{*}$ & $0.097 *$ & $0.063^{*}$ \\
\hline INF & $-6.54 \mathrm{E}-05^{\star}$ & $-0.000^{*}$ & $-0.000^{*}$ & $-1.59 \mathrm{E}-05^{\star}$ \\
\hline LNGFCF & $-0.010^{*}$ & $-0.000^{\star}$ & $-0.006^{*}$ & $-0.004^{\star}$ \\
\hline \multicolumn{5}{|c|}{ MODEL 2B: FI = f(LNEGLOB, IQ, LNGDP, INF, LNGFCF) } \\
\hline LNEGLOB & $-1.120^{*}$ & $-0.130^{*}$ & $0.078^{*}$ & $0.154^{\star}$ \\
\hline IQ & $-0.252^{\star}$ & $-0.021^{\star}$ & $0.050^{\star}$ & $0.013^{*}$ \\
\hline LNGDP & $0.390 *$ & $0.016^{*}$ & $0.037^{\star}$ & $0.056^{\star}$ \\
\hline INF & $3.103^{\star}$ & 3.67E-05* & $0.064^{\star}$ & $1.13 \mathrm{E}-05^{\star}$ \\
\hline LNGFCF & $-2.927^{\star}$ & $-0.002^{\star}$ & $0.041^{*}$ & $0.008^{\star}$ \\
\hline
\end{tabular}

Note: ${ }^{\star \star \star},{ }^{\star \star \star}$ are significant at $1 \%, 5 \%$ and $10 \%$ level respectively.

The long-run results of remittance and FDI-financial market nexus are described in Table 9C. The result shows a negative association in the ECA region and positive in the bottom remittance and FDI receiving region. But interestingly, it is entirely opposite in the case of FDI. However, foreign migrants prefer to invest their remittance in the stock market in the SSA region, which leads to positive growth of stock market development in this region. Here, institutional quality also behaves perfect channel of remittances as they are affected by the financial market with the same impact. SSA region is benefitted from high economic globalization, improved institutional quality, negative inflation rate, and positive economic growth. The bottom remittance-FDI receiving region only needs to focus critically on domestic investment, which helps to enhance financial market development by improving productivity and growth.

Model 3B shows the relationship between economic globalization and financial market development for the top and bottom remittance-receiving regions. Economic globalization and institutional quality positively impact the financial market in the ECA region, but it is adversely impacting the SSA region. Result proof that the top region is getting advantage from economic globalization, institutional quality, economic growth, domestic investment, and inflation rate to enhance the stock market development. Positive economic globalization helps the top region enhance relations with other economies to make a larger competitive market. This leads to a growing stock market, where foreign investors will more interest in investing their money for an attractive rate of return. However, the bottom remittance-receiving region is not benefitted from globalization and institutional quality. The high inflation rate may also be another reason for not getting benefits from economic globalization, as a high inflation rate can reduce employment and capital flows, which decreases growth and development in the bottom region. 
Therefore, a relatively well-developed stock market helps attract foreign investors; in that case, the bottom region needs to apply some new and updated policies that can enhance the stock market's growth than the other regions.

Please insert Table 9C

Table 9C. Fully modified ordinary least square (FMOLS) and Dynamic least squares (DOLS)

\begin{tabular}{|c|c|c|c|c|}
\hline \multirow[t]{2}{*}{ Variables } & \multicolumn{2}{|c|}{ Europe And Central Asian Region } & \multicolumn{2}{|c|}{ Sub-Saharan African Region } \\
\hline & $\begin{array}{l}\text { Fully Modified Ordinary } \\
\text { Least Square (FMOLS) }\end{array}$ & $\begin{array}{l}\text { Dynamic Ordinary } \\
\text { Least Square } \\
\text { (DOLS) }\end{array}$ & $\begin{array}{l}\text { Fully Modified Ordinary } \\
\text { Least Square (FMOLS) }\end{array}$ & $\begin{array}{l}\text { Dynamic Ordinary } \\
\text { Least Square } \\
\text { (DOLS) }\end{array}$ \\
\hline \multicolumn{5}{|c|}{ MODEL 3A: FM = f(LNREM, LNFDI, IQ, LNGDP, INF, LNGFCF) } \\
\hline LNREM & $-0.087^{\star}$ & $-0.004^{\star}$ & $0.044^{*}$ & $0.023^{\star}$ \\
\hline LNFDI & $0.006^{*}$ & $0.000 *$ & $-0.000 *$ & $-0.004 *$ \\
\hline IQ & $-0.004^{*}$ & $-0.027^{*}$ & $0.000 *$ & $0.004^{\star}$ \\
\hline LNGDP & $0.015^{\star}$ & $0.017^{*}$ & $0.001^{*}$ & $0.017^{*}$ \\
\hline INF & $0.005^{\star}$ & $1.78 \mathrm{E}-05^{\star}$ & $-3.99 \mathrm{E}-05^{\star}$ & $-0.000 * \star \star$ \\
\hline LNGFCF & $0.029 *$ & $0.001^{*}$ & $-0.000 *$ & $-0.001 *$ \\
\hline \multicolumn{5}{|c|}{ MODEL 3B: FM = f(LNEGLOB, IQ, LNGDP, INF, LNGFCF) } \\
\hline LNEGLOB & $0.140^{*}$ & $0.007 * \star$ & $-0.000^{*}$ & $-0.014^{*}$ \\
\hline IQ & $0.011^{\star}$ & $0.015^{\star}$ & $-9.03 E-05^{*}$ & $-0.000^{*}$ \\
\hline LNGDP & $0.027^{\star}$ & $-0.006^{\star}$ & $0.001^{*}$ & $0.004^{\star}$ \\
\hline INF & $0.000 *$ & 8.97E-06* & 1.17E-05* & $9.48 \mathrm{E}-06 *$ \\
\hline LNGFCF & $0.004 *$ & $0.000 *$ & $0.000^{*}$ & $0.000^{*}$ \\
\hline
\end{tabular}

Note: ${ }^{\star}{ }^{\star \star},{ }^{\star \star \star}$ are significant at $1 \%, 5 \%$ and $10 \%$ level respectively.

\section{Conclusion}

This paper investigates the relationship between financial development and remittance, FDI as well as economic globalization with some control variables, like, institutions quality, economic growth, inflation, and domestic investment, using data of European and Central Asian developing regions (15 countries) and Sub Saharan African developing region (29 countries) throughout the year of 1984-2020. As the concept of financial development is vast, we use various indicators that describe the various dimensions of financial institutions and markets; depth, access, and efficiency (Svirydzenka, 2016). We are also using a recently developed index value of economic globalization index that has been developed by Gygli et al., (2019). Based on this data set, we are estimating a comparison of the impact of remittance, FDI, and economic globalization with institutional quality and economic growth on financial development dynamics between the top and bottom remittance, FDI receiving region. 
Our study employs the FMOLS and DOLS approaches for estimation. We find that economic globalization positively impacts financial development for both the region if the institutional quality is at a satisfactory level. It shows that institutional quality is a pillar for growing globalization across the globe. This concept satisfies the Mishkin, (2009) hypothesis. The long-run partial elasticity of financial development with respect to change in remittance, $\mathrm{FDI}$, and economic globalization is positive for both panel regions. In the ECA region, FDI and economic globalization are harmful to the banking sector, which is positive for the SSA region. In the case of remittance, the ECA region has a positive effect on the banking sector but adversely affects the stock market. Though the SSA region receives only a tiny portion of the total recorded remittances to developing countries, but the paper finds that remittances positively impact financial development. This remittance amount reduces the budget constraints of migrant's households and gives a chance for the small savers to gain from the financial sector in the SSA region. FDI and economic globalization harms the stock market but positively impacted the banking sector in the SSA region. Based on the political economy argument, FDI inflows encourage the country's political policies by adopt new and modified market-friendly regulations, especially shielding investors from the risk and upgraded governance regulations, to promote the stock market development.

On the other hand, the well-structured stock market of emerging economies influences foreign investors. It is also happening in the developed economies more than the developing economies. Empirical evidence of this study illustrates that the increase in GDP per capita also boosts the financial development for both the region. The impact of other control variables and financial development produced mixed evidence.

The empirical results suggest some important future policy implications for the economic globalization and financial development. Our analysis suggests that globalization helps at the time of financial crisis by providing the sources of capital in developing countries. From a policy perspective, all developing countries should utilize the domestic financial sources more than the foreign capital flows and trade coming from outside the world. For that domestic financial system needs to be strong. To strengthen the domestic financial system, both regions need to implement an efficient supervisory and regulatory framework that diminishes the financial stability risks. On this note, macroeconomic policies such as monetary and fiscal policy, and exchange rate can play a major role in handling the financial risks of globalization. Suitable micro-prudential policies also use to elevate the durability. Strong international policy cooperation and cross-border supervision are mostly needed to alleviate the stability risks of foreign capital flows.

Further, developing institutional quality, mainly the rule of law, government effectiveness, and property rights, may stimulate the development of domestic markets than foreign markets. Success in terms of institutional quality and the quality of financial development will enable Sub-Saharan Africa economies to achieve a higher growth rate in the long run. Also, the point to be highlighted regarding remittance and FDI is that new policies need to implement for attract more investors by market-friendly banking and stock market regulations; mechanisms to improve governance and protect investors from the risk. As a result, countries can maximize the benefits of the spill over effects of international capital flows.

\section{Appendix}

High remittance and FDI receiving region, i.e., European and Central Asian region (15 Countries): Albania, Armenia, Azerbaijan, Belarus, Bulgaria, Croatia, Hungary, Kazakhstan, Moldova, Poland, Romania, Russian Federation, Serbia, Turkey, and Ukraine

Page 25/32 
Low remittance and FDI receiving region, i.e., Sub-Saharan African region (29 countries): Angola, Botswana, Burkina Faso, Cameroon, Congo, the Democratic Republic of the Congo, Côte d'Ivoire, Ethiopia, Gabon, Gambia, Ghana, Guinea, Guinea-Bissau, Kenya, Liberia, Madagascar, Malawi, Mali, Mozambique, Namibia, Niger, Nigeria, Senegal, Sierra Leone, South Africa, Tanzania, Togo, Uganda, and Zambia.

\section{Declarations}

Acknowledgements: Not applicable

Authors' contributions: The author read and approved the final manuscript.

Availability of data and materials: Available upon reasonable request from the corresponding author.

Competing interests: There is no conflict of interest.

Funding: Not applicable.

Authors' information: Shreya Pal is currently a research scholar in the Department of Humanities and Social Sciences at the Indian Institute of Technology, Kharagpur, West Bengal, India. Her research area includes international finance and macroeconomics. Her publications are found in journal of public affairs, international journal of economic policy studies.

\section{References}

1. Aggarwal R, Demirgüç-Kunt A, Pería MSM (2011) Do remittances promote financial development? J Dev Econ 96(2):255-264

2. Ahamada I, Coulibaly D (2011) How does financial development influence the impact of remittances on growth volatility? Econ Model 28(6):2748-2760

3. Aitken B, Hanson GH, Harrison AE (1997) Spillovers, foreign investment, and export behavior. J Int Econ 43(1-2):103-132

4. Ajayi SI (2006) The determinants of foreign direct investment in Africa: A survey of the evidence. Foreign Direct Investment in Sub-Saharan Africa: Origins, Targets, Impact and Potential

5. Akisik O (2013) Accounting regulation, financial development, and economic growth. Emerging Markets Finance and Trade 49(1):33-67

6. Alfaro L, Chanda A, Kalemli-Ozcan S, Sayek S (2004) FDI and economic growth: The role of local financial markets. J Int Econ 64(1):89-112

7. Alfaro L, Chanda A, Kalemli-Ozcan S, Sayek S (2010) Does foreign direct investment promote growth? Exploring the role of financial markets on linkages. J Dev Econ 91(2):242-256

8. Alfaro L, Kalemli-Ozcan S, Sayek S (2009) FDI, productivity and financial development. World Econ 32(1):111-135

9. Ang JB (2008) Are financial sector policies effective in deepening the Malaysian financial system? Contemp Econ Policy 26(4):623-635

10. Ang JB (2009) Financial development and the FDI-growth nexus: The Malaysian experience. Appl Econ 41(13):1595-1601 
11. Baharumshah AZ, Thanoon MA-M (2006) Foreign capital flows and economic growth in East Asian countries. China Econ Rev 17(1):70-83

12. Balasubramanyam VN, Salisu MA, Sapsford D (1996) Foreign direct investment, trade policy and economic growth. Trade and Development. Springer, pp 3-21

13. Baltagi BH, Demetriades PO, Law SH (2009) Financial development and openness: Evidence from panel data. J Dev Econ 89(2):285-296

14. Bang JT, Mitra A, Wunnava PV (2015) Financial liberalization and remittances: Recent panel evidence. The Journal of International Trade \& Economic Development 24(8):1077-1102

15. Basnet HC, Koirala B, Upadhyaya KP, Donou-Adonsou F (2021) Workers' remittances and financial development: The case of South Asia. International Review of Economics 68(2):185-207

16. Bayar Y, Gavriletea MD (2018) Foreign direct investment inflows and financial development in Central and Eastern European Union countries: A panel cointegration and causality. International Journal of Financial Studies 6(2):55

17. Beck T, Demirgüç-Kunt A, Levine R (2003) Law, endowments, and finance. J Financ Econ 70(2):137-181

18. Berument H, Dinçer NN (2004) Do capital flows improve macroeconomic performance in emerging markets?: The Turkish experience. Emerging Markets Finance and Trade 40(4):20-32

19. Bhattacharya M, Inekwe J, Paramati SR (2018) Remittances and financial development: Empirical evidence from heterogeneous panel of countries. Appl Econ 50(38):4099-4112

20. Bolarinwa ST, Akinbobola TO (2021) Remittances-financial development nexus: Causal evidence from four African countries. Ilorin Journal of Economic Policy 8(1):1-17

21. Borensztein E, De Gregorio J, Lee J-W (1998) How does foreign direct investment affect economic growth? J Int Econ 45(1):115-135

22. Brown RP, Carmignani F, Fayad G (2013) Migrants' remittances and financial development: Macro-and microlevel evidence of a perverse relationship. The World Economy 36(5):636-660

23. Burgess R, Pande R (2005) Do rural banks matter? Evidence from the Indian social banking experiment. Am Econ Rev 95(3):780-795

24. Burnside C, Dollar D (2000) Aid, policies, and growth. Am Econ Rev 90(4):847-868

25. Calderon C, Fajnzylber P, López JH (2008) Remittances and growth: The role of complementary policies. Remittances and Development: Lessons from Latin America, World Bank, Washington, DC

26. Chami R, Fullenkamp C, Jahjah S (2005) Are immigrant remittance flows a source of capital for development? IMF Staff Pap 52(1):55-81

27. Chen Y-L, Emile ES (2013) Trade openness and finance: Effects of foreign trade with China on Latin American financial development. Emerging Markets Finance and Trade 49(sup3):110-122

28. Chenery HB, Strout AM (1966) Foreign Assistance and Economic Development American Economic Review 56. September

29. Cherif M, Dreger C (2016) Institutional determinants of financial development in MENA countries. Rev Dev Econ 20(3):670-680

30. Chinn MD, Ito H (2006) What matters for financial development? Capital controls, institutions, and interactions. J Dev Econ 81(1):163-192 
31. Chowdhury MB (2011) Remittances flow and financial development in Bangladesh. Econ Model 28(6):26002608

32. Combes J-L, Ebeke C (2011) Remittances and household consumption instability in developing countries. World Dev 39(7):1076-1089

33. Cooray A, Dutta N, Mallick S (2016) Does female human capital formation matter for the income effect of remittances? Evidence from developing countries. Oxf Dev Stud 44(4):458-478

34. Coulibaly D (2015) Remittances and financial development in Sub-Saharan African countries: A system approach. Econ Model 45:249-258

35. De Gregorio J, Guidotti PE (1995) Financial development and economic growth. World Dev 23(3):433-448

36. De Mello LR Jr (1997) Foreign direct investment in developing countries and growth: A selective survey. J Dev Stud 34(1):1-34

37. De Mello LR (1999) Foreign direct investment-led growth: Evidence from time series and panel data. Oxf Econ Pap 51(1):133-151

38. Demetriades PO, Law SH (2006) Openness, institutions and financial development. World Economy \& Finance Research Programme

39. Djalilov K, Piesse J (2011) Financial development and growth in transition countries: A study of Central Asia. Emerging Markets Finance and Trade 47(6):4-23

40. Donou-Adonsou F, Pradhan G, Basnet HC (2020) Remittance inflows and financial development: Evidence from the top recipient countries in Sub-Saharan Africa. Appl Econ 52(53):5807-5820

41. Durham JB (2004) Absorptive capacity and the effects of foreign direct investment and equity foreign portfolio investment on economic growth. Eur Econ Rev 48(2):285-306

42. Durusu-Ciftci D, Ispir MS, Yetkiner H (2017) Financial development and economic growth: Some theory and more evidence. J Policy Model 39(2):290-306

43. Fromentin V (2017) The long-run and short-run impacts of remittances on financial development in developing countries. The Quarterly Review of Economics and Finance 66:192-201

44. Fromentin V (2018) Remittances and financial development in Latin America and the Caribbean countries: A dynamic approach. Rev Dev Econ 22(2):808-826

45. Fung MK (2009) Financial development and economic growth: Convergence or divergence? J Int Money Finance 28(1):56-67

46. Giuliano P, Ruiz-Arranz M (2009) Remittances, financial development, and growth. J Dev Econ 90(1):144-152

47. Griffin K, McKinley T (1994) A new framework for development cooperation. UNDP Human Development Report Office

48. Grilli V, Milesi-Ferretti GM (1995) Economic effects and structural determinants of capital controls. Staff Papers 42(3):517-551

49. Gupta S, Pattillo CA, Wagh S (2009) Effect of remittances on poverty and financial development in SubSaharan Africa. World Dev 37(1):104-115

50. Gygli S, Haelg F, Potrafke N, Sturm J-E (2019) The KOF globalisation index-revisited. The Review of International Organizations 14(3):543-574

51. Haddad M, Harrison A (1993) Are there positive spillovers from direct foreign investment?: Evidence from panel data for Morocco. J Dev Econ 42(1):51-74

Page 28/32 
52. Hajilee M, Nasser OMA (2015) The relationship between financial market development and foreign direct investment in Latin American countries. The Journal of Developing Areas,227-245

53. Hanif A, Shariff SSM (2016) Relationship between foreign direct investment and financial development. Proceedings of the 1st AAGBS International Conference on Business Management 2014 (AiCoBM 2014), 457-467

54. Hansen H, Rand J (2006) On the causal links between FDI and growth in developing countries. World Econ 29(1):21-41

55. Harrison AE, Aitken BJ (1999) Do domestic firms benefit from direct foreign investment? Evidence from Venezuela. Am Econ Rev 89(3):605-618

56. Henri N, Luc NN, Larissa N (2019) The long-run and short-run effects of foreign direct investment on financial development in African countries. Afr Dev Rev 31(2):216-229

57. Hermes N, Lensink R (2003) Foreign direct investment, financial development and economic growth. J Dev Stud 40(1):142-163

58. Hsueh S-J, Hu Y-H, Tu C-H (2013) Economic growth and financial development in Asian countries: A bootstrap panel Granger causality analysis. Econ Model 32:294-301

59. Ikpesu F, Akinola A, Ikpesu A, O (2020) Remittance flows and banking sector development in emerging markets: Do institutions matter? Journal of Transnational Management,1-12

60. Im KS, Pesaran MH, Shin Y (2003) Testing for unit roots in heterogeneous panels. J Econ 115(1):53-74

61. Kandil M, Shahbaz M, Nasreen S (2015) The interaction between globalization and financial development: New evidence from panel cointegration and causality analysis. Empirical Economics 49(4):1317-1339

62. Kao C, Chiang M-H (2001) On the estimation and inference of a cointegrated regression in panel data. Nonstationary panels, panel cointegration, and dynamic panels. Emerald Group Publishing Limited

63. Kim D-H, Lin S-C, Suen Y-B (2010) Dynamic effects of trade openness on financial development. Econ Model 27(1):254-261

64. King RG, Levine R (1993) Finance and growth: Schumpeter might be right. Q J Econ 108(3):717-737

65. Kosack S, Tobin J (2006) Funding self-sustaining development: The role of aid, FDI and government in economic success. Int Org 60(1):205-243

66. Law SH (2008) Does a country's openness to trade and capital accounts lead to financial development? Evidence from Malaysia. Asian Econ J 22(2):161-177

67. Law SH, Azman-Saini WNW, Tan HB (2014) Economic globalization and financial development in East Asia: A panel cointegration and causality analysis. Emerging Markets Finance and Trade 50(1):210-225

68. Levine R (2003) More on finance and growth: More finance, more growth? Review-Federal Reserve Bank of Saint Louis 85(4):31-46

69. Liu W-C, Hsu C-M (2006) The role of financial development in economic growth: The experiences of Taiwan, Korea, and Japan. J Asian Econ 17(4):667-690

70. Mah JS (2010) Foreign direct investment inflows and economic growth: The case of Korea. Rev Dev Econ 14(4):726-735

71. Majeed A, Jiang P, Ahmad M, Khan MA, Olah J (2021) The Impact of Foreign Direct Investment on Financial Development: New Evidence from Panel Cointegration and Causality Analysis. J Compet 13:95-112

72. Mishkin FS (2009) Globalization and financial development. J Dev Econ 89(2):164-169 
73. Mundaca BG (2009) Remittances, financial market development, and economic growth: The case of Latin America and the Caribbean. Rev Dev Econ 13(2):288-303

74. Muye IM, Muye IY (2017) Testing for causality among globalization, institution and financial development: Further evidence from three economic blocs. Borsa Istanbul Review 17(2):117-132

75. Nasreen S, Mahalik MK, Shahbaz M, Abbas Q (2020) How do financial globalization, institutions and economic growth impact financial sector development in European countries? Research in International Business and Finance 54:101247

76. Nazlioglu S, Yalama A, Aslan M (2009) Financial development and investment: Cointegration and causality analysis for the case of Turkey. International Journal of Economic Perspectives 3(2):107-119

77. Nyamongo EM, Misati RN, Kipyegon L, Ndirangu L (2012) Remittances, financial development and economic growth in Africa. J Econ Bus 64(3):240-260

78. Otchere I, Soumaré I, Yourougou P (2016) FDI and financial market development in Africa. The World Economy 39(5):651-678

79. Pal S, Kumar Mahalik M (n.d.). Factors driving financial development in top and bottom globalized developing economies: Does economic globalization matter? Journal of Public Affairs, e2292

80. Pedroni P (2004) Panel cointegration: Asymptotic and finite sample properties of pooled time series tests with an application to the PPP hypothesis. Econom Theory 20(3):597-625

81. Pesaran $\mathrm{MH}$ (2007) A simple panel unit root test in the presence of cross-section dependence. J Appl Econom 22(2):265-312

82. Pradhan G, Upadhyay M, Upadhyaya K (2008) Remittances and economic growth in developing countries. The European Journal of Development Research 20(3):497-506

83. Rajan RG, Zingales $L$ (2003) The great reversals: The politics of financial development in the twentieth century. J Financ Econ 69(1):5-50

84. Rapoport H, Docquier F (2006) The economics of migrants' remittances. Handbook of the Economics of Giving, Altruism and Reciprocity 2:1135-1198

85. Raza SA, Jawaid ST (2014) Foreign capital inflows, economic growth and stock market capitalization in Asian countries: An ARDL bound testing approach. Qual Quant 48(1):375-385

86. Rousseau PL, Sylla R (2007) 8 Financial Systems, Economic Growth, and Globalization. University of Chicago Press

87. Saidi K, Mbarek MB, Amamri M (2018) Causal dynamics between energy consumption, ICT, FDI, and economic growth: Case study of 13 MENA countries. Journal of the Knowledge Economy 9(1):228-238

88. Shahbaz M, Nasir MA, Roubaud D (2018) Environmental degradation in France: The effects of FDI, financial development, and energy innovations. Energy Econ 74:843-857

89. Shahbaz M, Van Hoang TH, Mahalik MK, Roubaud D (2017) Energy consumption, financial development and economic growth in India: New evidence from a nonlinear and asymmetric analysis. Energy Econ 63:199212

90. Siddiqui K (2014) Flows of foreign capital into developing countries: A critical review. Journal of International Business and Economics 2(1):29-46

91. Sobiech I (2015) Remittances, finance and growth: Does financial development foster remittances and their impact on economic growth. FIW Working Paper

Page $30 / 32$ 
92. Soumaré I, Tchana Tchana F (2015) Causality between FDI and financial market development: Evidence from emerging markets. World Bank Econ Rev 29(suppl1):S205-S216

93. Stock JH, Watson MW (1993) A simple estimator of cointegrating vectors in higher order integrated systems. Econometrica: Journal of the Econometric Society,783-820

94. Svirydzenka K (2016) Introducing a new broad-based index of financial development. International Monetary Fund

95. Tsagkanos A, Siriopoulos C, Vartholomatou K (2019) Foreign direct investment and stock market development: Evidence from a "new" emerging market. Journal of Economic Studies

96. Westerlund $\mathrm{J}$ (2012) Testing for unit roots in panel time-series models with multiple level breaks. The Manchester School 80(6):671-699

97. Williams K (2016) Remittances and financial development: Evidence from sub-Saharan Africa. Afr Dev Rev 28(3):357-367

98. Zhang D, Wu Y (2012) Household savings, the stock market, and economic growth in China. Emerging Markets Finance and Trade 48(2):44-58

\section{Figures}

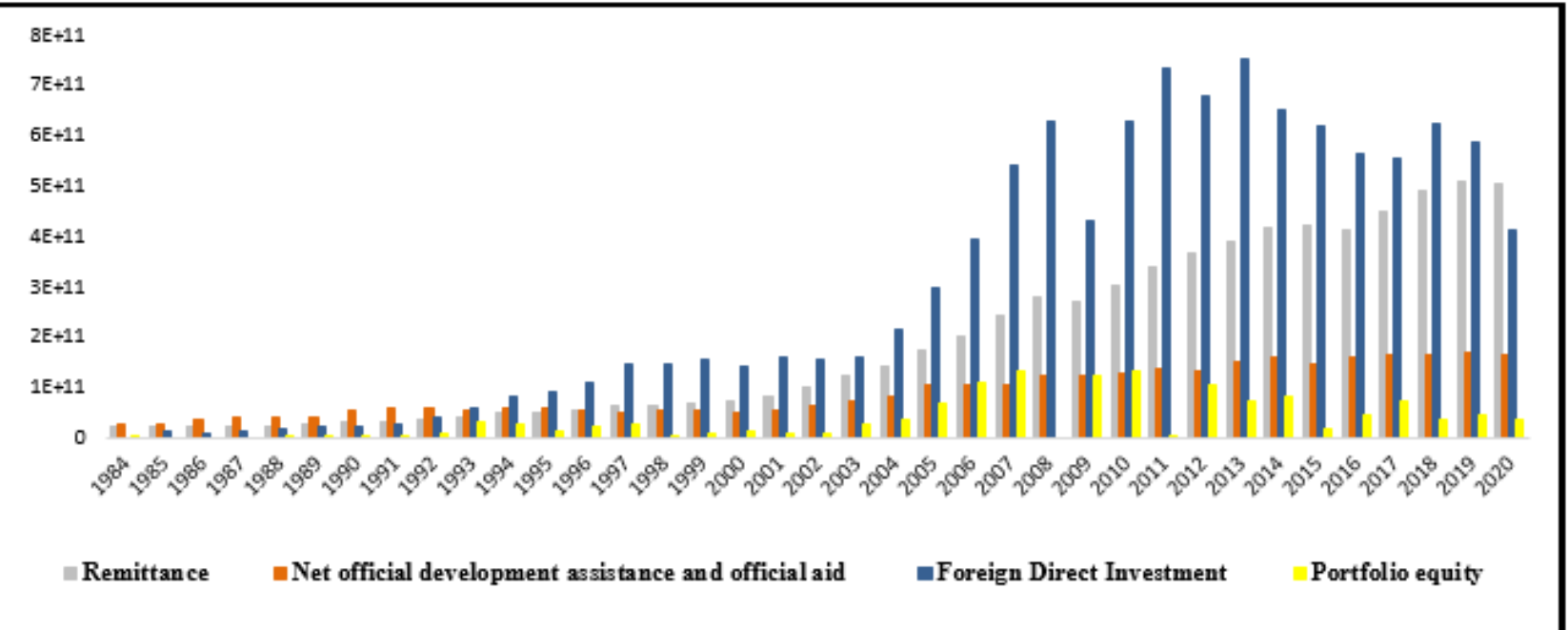

\section{Figure 1}

Resource flows to developing countries (US\$ billions)

Data Source: World Development Indicators. 


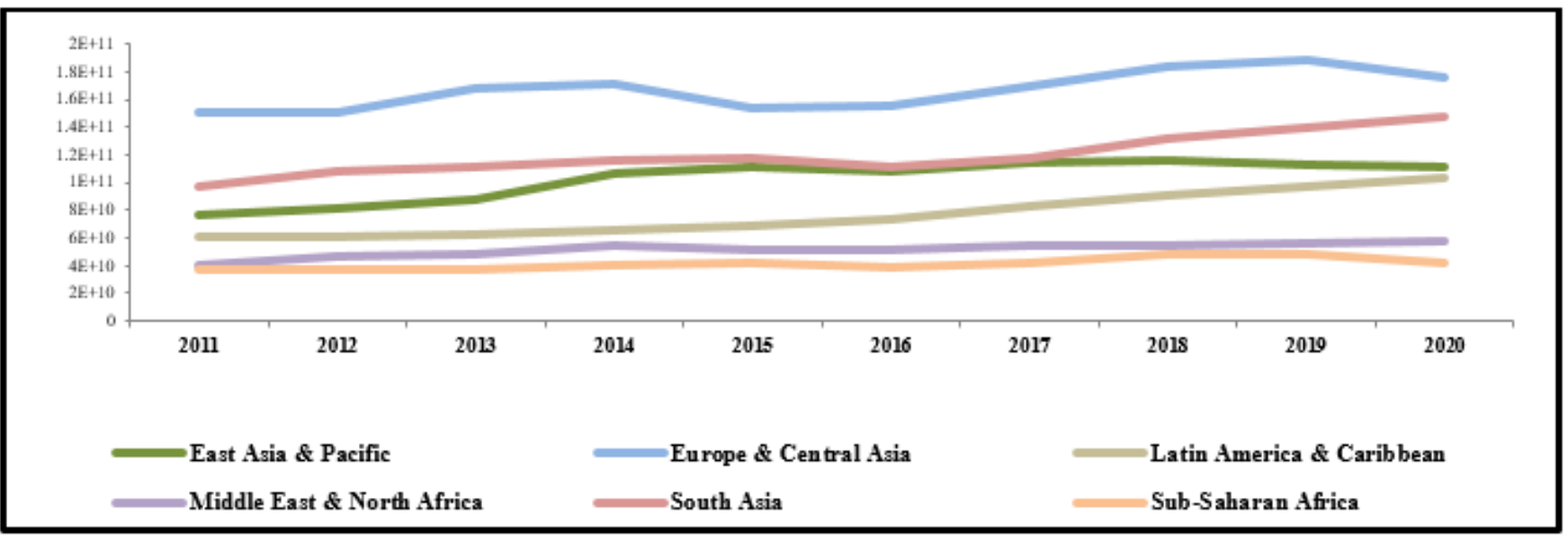

Figure 2

Personal remittances, received (current US\$)

Data source: World Development Indicators

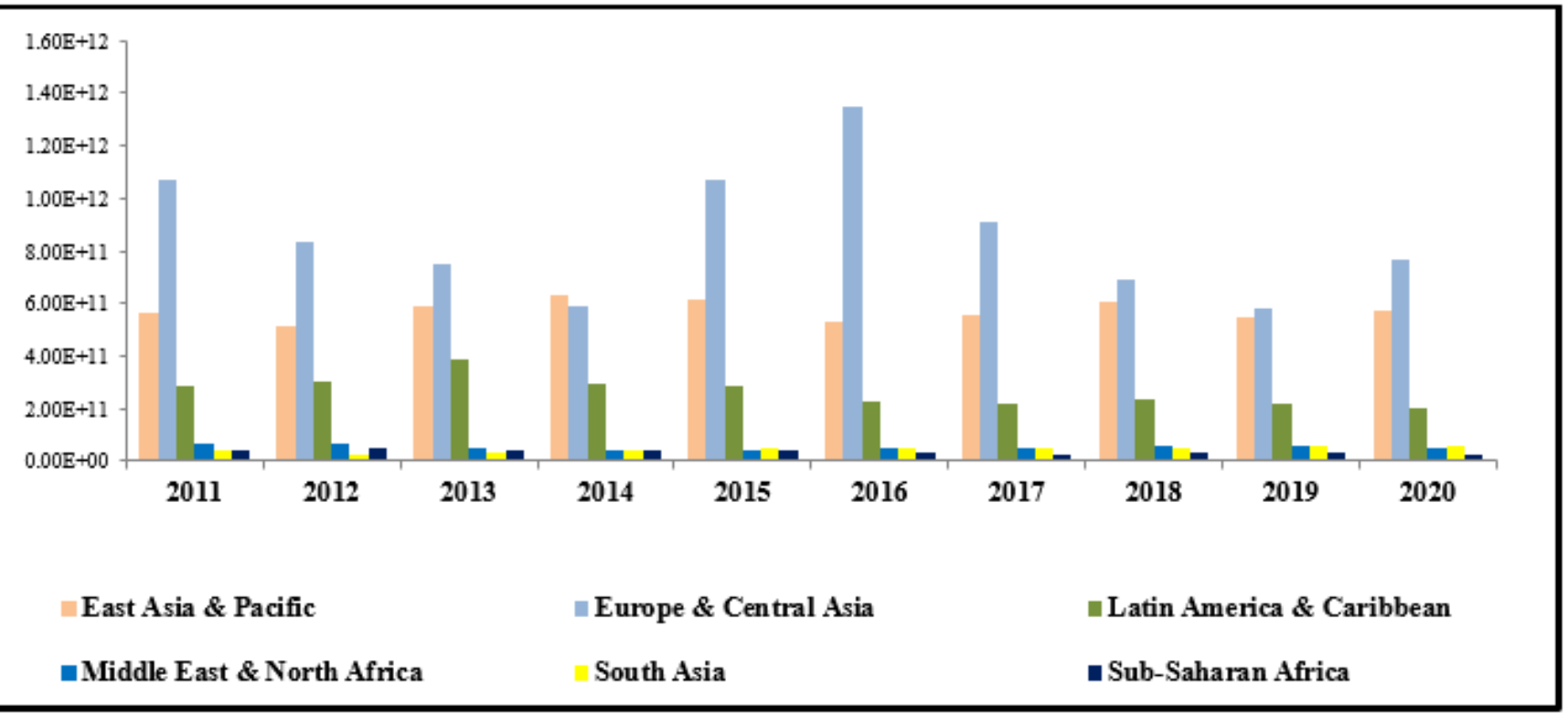

Figure 3

Foreign direct investment, net inflows (Current US\$)

Data source: World Development Indicators 